\title{
Article \\ Synthesis and Characterization of New Boron Compounds Using Reaction of Diazonium Tetraphenylborate with Enaminoamides
}

\author{
Markéta Svobodová $^{1, *} \mathbb{0}$, Jan Svoboda ${ }^{1} \mathbb{C}$, Bing-Han Li $^{2}$, Valerio Bertolasi ${ }^{3}$, Luboš Socha ${ }^{1}$, Miloš Sedlák $^{1} \mathbb{C}$ \\ and Lukáš Marek ${ }^{1}$ \\ 1 Faculty of Chemical Technology, Institute of Organic Chemistry and Technology, University of Pardubice, \\ Studentská 573, 53210 Pardubice, Czech Republic; jan.svoboda@upce.cz (J.S.); st46953@upce.cz (L.S.); \\ milos.sedlak@upce.cz (M.S.); lukas.marek3@student.upce.cz (L.M.) \\ 2 Department of Chemistry, National Tsing Hua University, Hsinchu 30013, Taiwan; w6520325@hotmail.com \\ 3 Department of Chemical and Pharmaceutical Sciences, University of Ferrara, \\ Via L. Borsari 46, 44121 Ferrara, Italy; m38@unife.it \\ * Correspondence: marketa.svobodova@upce.cz
}

check for

updates

Citation: Svobodová, M.; Svoboda, J.;

Li, B.-H.; Bertolasi, V.; Socha, L.;

Sedlák, M.; Marek, L. Synthesis and Characterization of New Boron

Compounds Using Reaction of

Diazonium Tetraphenylborate with

Enaminoamides. Molecules 2022, 27,

367. https://doi.org/10.3390/

molecules27020367

Academic Editor:

Radosław Podsiadły

Received: 12 December 2021

Accepted: 4 January 2022

Published: 7 January 2022

Publisher's Note: MDPI stays neutral with regard to jurisdictional claims in published maps and institutional affiliations.

Copyright: () 2022 by the authors Licensee MDPI, Basel, Switzerland. This article is an open access article distributed under the terms and conditions of the Creative Commons Attribution (CC BY) license (https:// creativecommons.org/licenses/by/ $4.0 /)$.

\begin{abstract}
A family of oxazaborines, diazaborinones, triazaborines, and triazaborinones was prepared by reaction of polarized ethylenes, such as $\beta$-enaminoamides, with 4-methylbenzenediazonium tetraphenylborates. The reaction conditions (stirring in $\mathrm{CH}_{2} \mathrm{Cl}_{2}$ at room temperature (Method A) or stirring with $\mathrm{CH}_{3} \mathrm{COONa}$ in $\mathrm{CH}_{2} \mathrm{Cl}_{2}$ at room temperature (Method B) or refluxing in the $\mathrm{CH}_{2} \mathrm{Cl}_{2}$ /toluene mixture (Method C)) controlled the formation and relative content of these compounds in the reaction mixtures from one to three products. Substituted oxazaborines gradually rearranged into diazaborinones at $250{ }^{\circ} \mathrm{C}$. The prepared compounds were characterized by ${ }^{1} \mathrm{H}$ NMR, ${ }^{13} \mathrm{C}$ NMR, IR, and UV-Vis spectroscopy, HRMS, or microanalysis. The structure of individual compounds was confirmed by ${ }^{11} \mathrm{~B}$ NMR, ${ }^{15} \mathrm{~N}$ NMR, 1D NOESY, and X-ray analysis. The mechanism of reaction of enaminoamides with 4-methylbenzenediazonium tetraphenylborate was proposed.
\end{abstract}

Keywords: boron; enaminoamide; oxazaborine; diazaborinone; triazaborine; triazaborinone

\section{Introduction}

Activated alkenes, also known as polarized ethylenes, are molecules containing a double bond with the electron-withdrawing group $\left(-\mathrm{C}=\mathrm{O},-\mathrm{CN},-\mathrm{NO}_{2}\right.$, etc. $)$ at one end and electron-donating groups (typically amino groups) at the other. A molecule with such an arrangement of groups is referred to as "push-pull" ethylene. Due to their versatile reactivity, they are important building blocks for the syntheses of a wide variety of different heterocyclic systems with practical usability. $\beta$-Enaminoamides $\mathbf{1}$ (Figure 1 ) also belong among representatives of the polarized ethylenes. The oxygen of the amide function donates the free electron pair, and the amino group in $\beta$-position of the double bond is able to withdraw it.<smiles>[R][R]([R])=Cc1ccccc1</smiles>

Figure 1. General structure of simple enaminoamides. 
Compounds $\mathbf{1}$ have been used for the synthesis of uracil derivatives that inhibit histone deacetylase (HDAC), and these compounds have been efficient in inhibiting human recombinant (hr) HDAC1 [1]. Compounds 1 have been also used in the synthesis of dihydropyridines [2-6], and these dihydropyridines have been tested in cloned human $\alpha$ adrenoceptors, as well as the rat L-type calcium channel [4] or platelet activating factor (PAF) antagonist activity was measured [3]. Enaminoamides $\mathbf{1}$ can be used in the synthesis of other types of heterocycles, for example, pyridines [7], pyridine-2-one [8], pyrimidines [9], pyrimidinones [10-13], spirocyclohexane [14], 1H-pyrrole-2,3-dione [15], 2-oxopyrrole [11], pyrazolone [16], and isothiazole [17]. The coordination ability of these simple compounds has not been studied yet. The first mention is from November $2017[18,19]$, where the authors tested prepared oxazaborines (Scheme 1) for inhibition of the NLRP3 inflammasome in vitro and in vivo without affecting $\mathrm{Ca}^{2+}$ homeostasis.

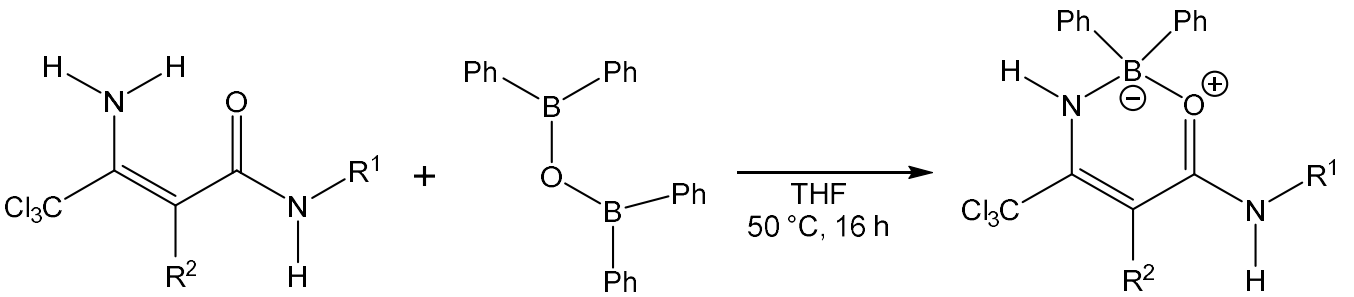

$\mathrm{R}^{1}=\mathrm{H}, \mathrm{Me}, \mathrm{Ph}, \mathrm{CH}_{2} \mathrm{Ph}, \mathrm{CH}_{2} \mathrm{CH}_{2} \mathrm{Ph}$, adamantyl, cyclohexyl, pyren-1-yl, pyridin-4-yl $\mathrm{R}^{2}=\mathrm{H}, \mathrm{COMe}, \mathrm{CONH}_{2}, \mathrm{CN}$

Scheme 1. Synthesis of oxazaborines according to Baldwin et al.

We have studied the reactions of polarized ethylenes, such as $\beta$-enaminones, $\beta$ enaminonitriles, and $\beta$-enaminoamides, with substitution on the amino group, with diazonium salts, leading to heterocyclic compounds. These compounds are pyridazines [20-22], pyrazoles [23-26], oxazaborines, diazaborinones, and triazaborines [27-31]. In 2009, we published work on the reaction of $\beta$-enaminoamides $\mathbf{1}$ (Figure $1, \mathrm{R}^{3}=\mathrm{Ph}$ ) and 4methylbenzenediazonium tetraphenylborate to give compounds I-III (Scheme 2) [28]. The ring transformation of compound I to diazaborinones II (predominantly when $\mathrm{R}^{1}=\mathrm{Me}$ ) and triazaborines III (predominantly when $\mathrm{R}^{1}=\mathrm{H}$ ) was proceeded under reflux in $N, N$ dimethylformamide [28]. We decided to change the substitution at the nitrogen atom of the amide group of enaminoamides as the basis for this paper. In the new study on enaminoamide reactivity, we report on synthetic transformations leading to $\mathrm{N}-\mathrm{B}-\mathrm{O}, \mathrm{N}-\mathrm{B}-\mathrm{N}$, and newly also $\mathrm{N}-\mathrm{N}-\mathrm{B}-\mathrm{N}-\mathrm{C}(=\mathrm{O})$ heterocyclic systems using the reactions of $\beta$-enaminoamides $\mathbf{1}$ (Figure $1, \mathrm{R}^{3}=\mathrm{H}, \mathrm{Me}$ ) and diazonium salts.
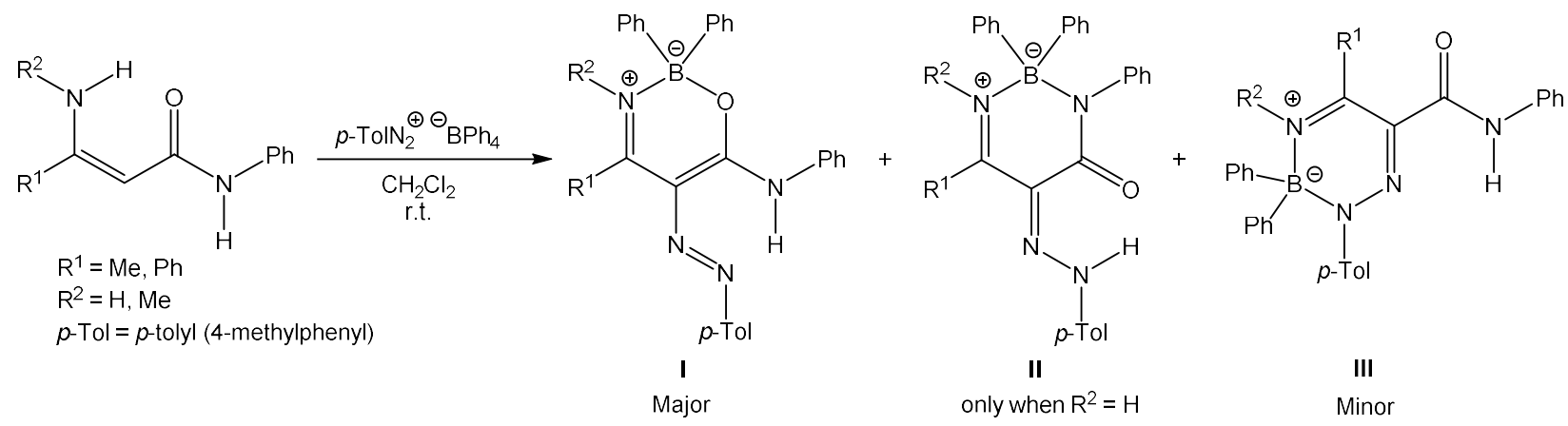

Scheme 2. Reaction of $N$-phenylenaminoamides and 4-methylbenzenediazonium tetraphenylborate. 


\section{Results and Discussion}

\subsection{Synthesis}

We prepared eight enaminoamides 1a-h (Supplementary Material, Scheme S1). The synthesis proceeded via an addition-elimination mechanism of the corresponding oxoamides with ammonia or methylamine. Oxoamides (except acetoacetamide (4a)) were obtained in two (compound $4 \mathrm{~b}$ [32]) or three (compounds $4 \mathrm{c}$ and $4 \mathrm{~d}$ ) steps from ethyl benzoylacetate and ethyl acetoacetate, respectively. Compound $4 \mathrm{~b}$ was prepared according to G. A. M. Giardina [32]. For the preparation of oxoamides $4 \mathbf{c}$ and $\mathbf{4 d}$, the synthetic procedure according to B. Štefane and S. Polanc was used [33]. This method consists of activation of the carboxy group with $\mathrm{BF}_{3}-\mathrm{Et}_{2} \mathrm{O}$, substitution of the alkoxy group, and hydrolysis to give oxoamide $4 \mathrm{c}$ and $\mathbf{4 d}$, or aminolysis to give enaminoamide $\mathbf{1 h}$.

Prepared enaminoamides $\mathbf{1} \mathbf{a}-\mathbf{h}$ reacted with 4-methylbenezenediazonium tetraphenylborate under three different conditions: (1) Stirring in $\mathrm{CH}_{2} \mathrm{Cl}_{2}$ at room temperature (Method A), (2) Stirring with $\mathrm{CH}_{3} \mathrm{COONa}$ in $\mathrm{CH}_{2} \mathrm{Cl}_{2}$ at room temperature (Method $\mathrm{B}$ ), and (3) Refluxing in the $\mathrm{CH}_{2} \mathrm{Cl}_{2}$ /toluene mixture (Method $\mathrm{C}$ ).

Figure 2 shows five possible product structures (A-E) for the reaction of enaminoamides 1a-h with 4-methylbenzenediazonium tetraphenylborate.<smiles></smiles>

A

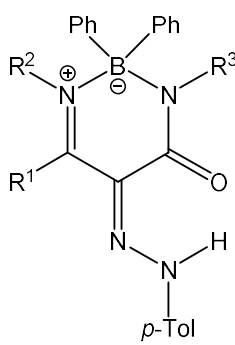

B<smiles></smiles>

C

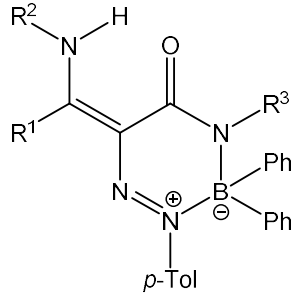

D

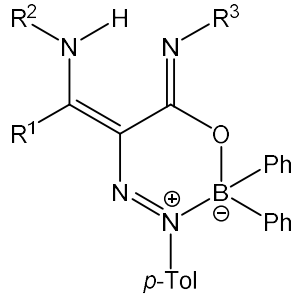

$\mathrm{E}$

$$
\begin{aligned}
& R^{1}=M e, P h \\
& R^{2}=R^{3}=H, M e
\end{aligned}
$$

Figure 2. Possible products of the reaction of enaminoamides $\mathbf{1 a}-\mathbf{h}$ with 4 -methylbenzenediazonium tetraphenylborate.

When $\beta$-enaminoamide 1c (Figure $1, \mathrm{R}^{1}=\mathrm{R}^{2}=\mathrm{Me}, \mathrm{R}^{3}=\mathrm{H}$ ) reacted with diazonium salt under heating with the mixture solvent (dichloromethane/toluene), the only product with a yield of $69 \%$ was isolated. The structure of this product was deduced on the basis of ${ }^{1} \mathrm{H},{ }^{13} \mathrm{C},{ }^{11} \mathrm{~B}$, and ${ }^{15} \mathrm{~N}-\mathrm{NMR}$ spectroscopy. In the aliphatic part of the ${ }^{1} \mathrm{H}$ NMR spectrum of this product (Supplementary Material, Figure S12), there are three signals of three methyl groups. One of them is a doublet, and two of them are singlets. The presence of a doublet is only possible for structures $\mathbf{D}$ and $\mathbf{E}$ (Figure $2, \mathrm{R}^{1}=\mathrm{R}^{2}=\mathrm{Me}$, $\mathrm{R}^{3}=\mathrm{H}$ ). The 1D NOESY spectrum (Figure 3) helped us to exclude one of these suggested structures. The through-space interaction between the proton with $\delta=5.52 \mathrm{ppm}$ and the ortho protons of the phenyl groups on the boron atom was found after the selective excitation of this $\mathrm{N}-\mathrm{H}$ proton (An analogue experiment was also carried out in the case of compounds 5a, 5b, 5g. Supplementary Material, Figures S2, S7 and S22). This interaction is not possible for structure $\mathbf{E}$. The structure of triazaborinone $\mathbf{D}$ suggested on the basis of NMR experiments was subsequently confirmed by X-ray diffraction (Figure 4). This is the new type of heterocycle in the series of enaminoamides $\mathbf{1}$, where the substituent on the nitrogen of the amide group is not phenyl. In the case of $N$-phenylenaminoamides, triazaborinones were not isolated. 


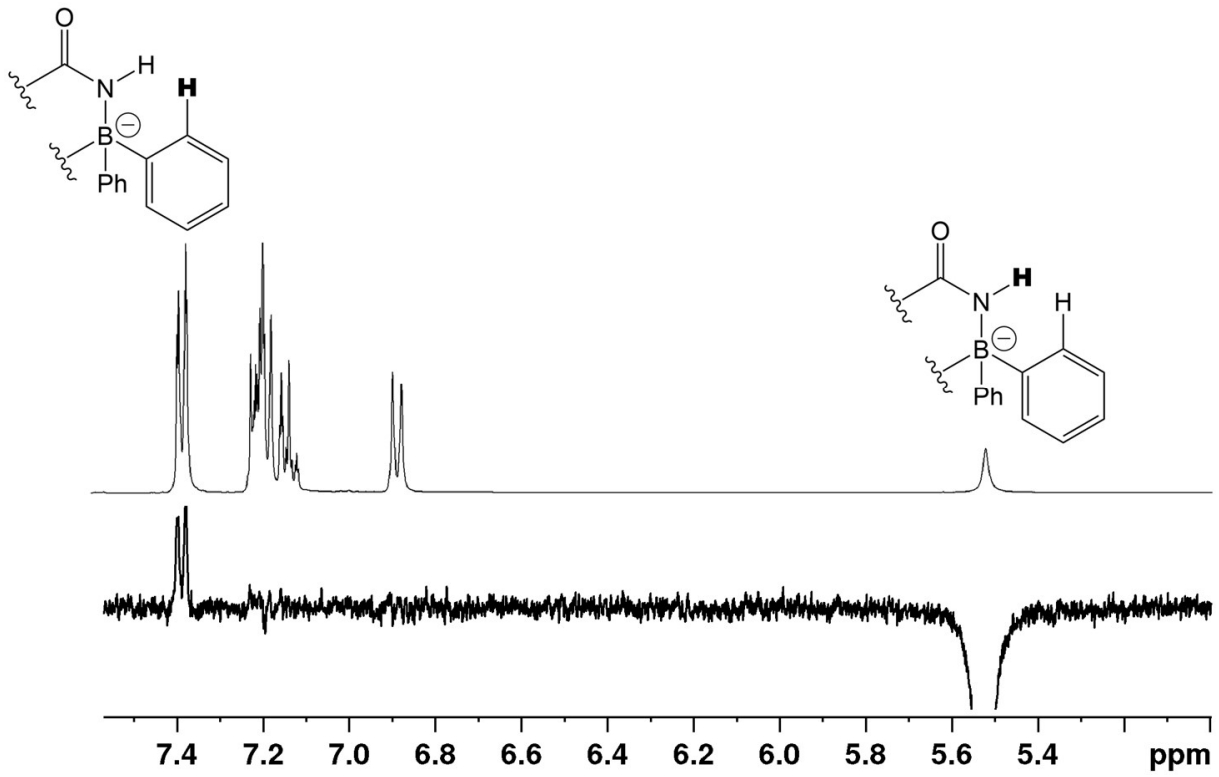

Figure 3. The $400 \mathrm{MHz} 1 \mathrm{D}-\mathrm{NOESY}$ (mixing time $\mathrm{d} 8=800 \mathrm{~ms}$, relaxation delay $\mathrm{d} 1=2 \mathrm{~s}$ ) of compound $5 \mathrm{c}$ in $\mathrm{CDCl}_{3}$.

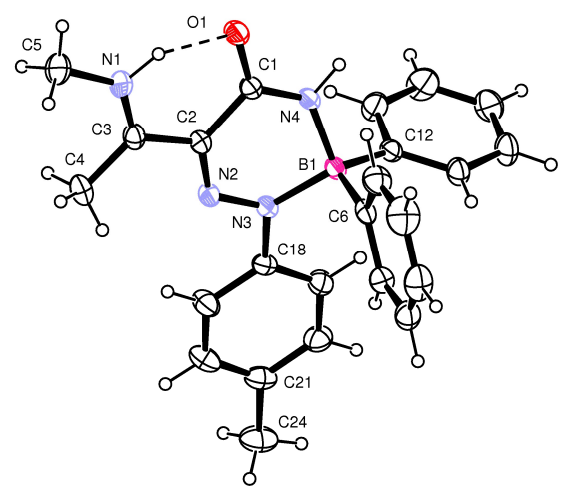

Figure 4. ORTEP view and atom numbering scheme for $5 \mathrm{c}$. Thermal ellipsoids are drawn at the $50 \%$ probability level.

We isolated the new type of boron heterocycle in six cases. When enaminoamides $\mathbf{1 a}-\mathbf{d}, \mathbf{1 g}$, and $\mathbf{1 h}$ reacted with diazonium salt, the new triazaborinones $\mathbf{5}$ were obtained as major compounds together with oxazaborines 6 , diazaborinones 7 , or triazaborines 8 as minor products (Scheme 3). Oxazaborine 6a was also prepared from 3-aminobut-2-ennitrile and diazonium tetraphenylborate, as described in [30].<smiles>[R]NC(=O)/C=C(/[R])N[R]</smiles>

1a: $R^{1}=M e, R^{2}=R^{3}=H$ 1b: $R^{1}=P h, R^{2}=R^{3}=H$ 1c: $R^{1}=R^{2}=M e, R^{3}=H$

1d: $R^{1}=P h, R^{2}=M e, R^{3}=H$ 1g: $R^{1}=R^{2}=R^{3}=M e$

1h: $R^{1}=P h, R^{2}=R^{3}=M e$<smiles>Cc1ccc(N=[Se]Oc2ccccc2)cc1</smiles>

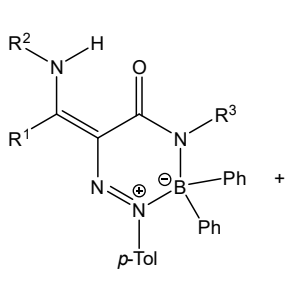

5a-d, 5g,h major<smiles></smiles>

$6 a, g$

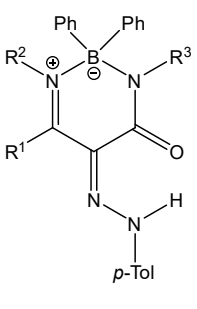

7b-d,7g,h minor

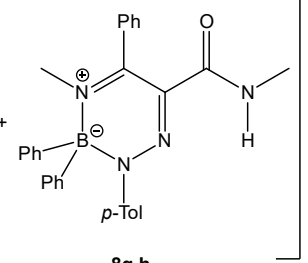

Scheme 3. The reaction of enaminoamides $1 \mathrm{a}-\mathrm{d}, \mathbf{1 g}$, and $\mathbf{1 h}$. 
When enaminoamides $1 \mathbf{e}$ and $\mathbf{1 f}$ reacted with diazonium tetraphenylborate, only oxazaborines and diazaborinones were isolated (Scheme 4). Triazaborine 8e was also isolated when enaminoamide $1 \mathbf{e}$ and diazonium salt were refluxed after stirring $30 \mathrm{~min}$ at room temperature. The yield of $8 \mathbf{e}$ was $26 \%$.

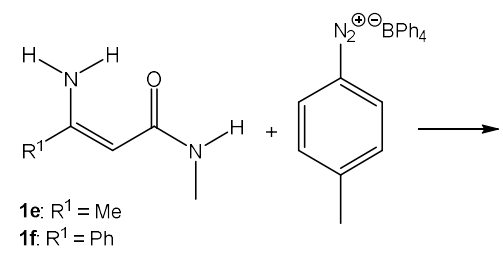

Scheme 4. The reaction of enaminoamides $1 \mathrm{e}$ and $\mathbf{1 f}$.

The yields of the prepared heterocyclic boron compounds are shown in Table 1, and their values are given either after crystallization or after washing with an appropriate solvent.

Table 1. Yields of boron compounds prepared under three different reaction conditions.

\begin{tabular}{|c|c|c|c|c|}
\hline \multirow[b]{2}{*}{$\begin{array}{l}\text { Starting } \\
\text { Amide }\end{array}$} & \multirow[b]{2}{*}{ Products } & \multicolumn{3}{|c|}{ Yield (\%) } \\
\hline & & $\begin{array}{l}\text { Method A: } \\
\quad \mathrm{CH}_{2} \mathrm{Cl}_{2} \\
\text { r.t., } 72-104 \mathrm{~h}\end{array}$ & $\begin{array}{c}\text { Method B: } \\
\mathrm{CH}_{3} \mathrm{COONa} / \mathrm{CH}_{2} \mathrm{Cl}_{2} \\
\text { r.t., } 72 \mathrm{~h}\end{array}$ & $\begin{array}{l}\text { Method C: } \\
\mathrm{CH}_{2} \mathrm{Cl}_{2} \text { /Toluene } \\
\text { 1. r.t., } 30 \text { min. } \\
\text { 2. Reflux, 2.5-5 h }\end{array}$ \\
\hline \multirow{2}{*}{$1 \mathrm{a}$} & Triazaborine $\mathbf{5 a}$ & 61 & 58 & 61 \\
\hline & Oxazaborine $\mathbf{6 a}$ & 4 & 7 & - \\
\hline \multirow[b]{2}{*}{$1 b$} & Triazaborine $\mathbf{5 b}$ & 50 & 37 & 55 \\
\hline & Diazaborinone $7 \mathbf{b}$ & 10 & 21 & - \\
\hline \multirow{2}{*}{ 1c } & Triazaborine $5 c$ & 43 & 48 & 69 \\
\hline & Diazaborinone 7c & - & 8 & - \\
\hline \multirow{2}{*}{$1 d$} & Triazaborine $5 \mathrm{~d}$ & 65.5 & 79 & 68.5 \\
\hline & Diazaborinone 7d & 1.7 & 10.5 & 9.6 \\
\hline \multirow{3}{*}{$1 e$} & Oxazaborine 6 e & 29 & 51 & 32 \\
\hline & Diazaborinone 7e & 27 & - & 16 \\
\hline & Triazaborine 8e & - & - & 26 \\
\hline \multirow{2}{*}{$1 f$} & Oxazaborine $6 f$ & 8 & 43 & 21 \\
\hline & Diazaborinone 7f & 51 & 9 & 13 \\
\hline \multirow{4}{*}{$1 g$} & Triazaborinone $5 \mathrm{~g}$ & 26 & 30 & 48 \\
\hline & Oxazaborine $\mathbf{6 g}$ & 32 & 17 & 5.4 \\
\hline & Diazaborinone $\mathbf{7 g}$ & - & - & 6.3 \\
\hline & Triazaborine $\mathbf{8 g}$ & - & - & 2.4 \\
\hline \multirow{4}{*}{ 1h } & Triazaborinone $5 \mathbf{h}$ & - & - & 15 \\
\hline & Oxazaborine $\mathbf{6 h}$ & 22 & - & - \\
\hline & Diazaborinone $\mathbf{7 h}$ & 3 & - & 16 \\
\hline & Triazaborine $\mathbf{8 h}$ & - & - & 21 \\
\hline
\end{tabular}

-: Not obtained.

We suggested the mechanism for the reaction of enaminones with diazonium tetraphenylborates [27]. In the first step, the azocoupling reaction proceeds in which tetraphenylborate acts as a base and during which the protodeboronation of $\mathrm{Ph}_{3} \mathrm{~B}^{-}-\left[\mathrm{C}_{6} \mathrm{H}_{6}\right]^{+}$occurs to give triphenylborane and benzene [27]. Triphenylborane is able to coordinate to the nitrogen atom of the amine group of enaminones followed by further protodeboronation and cyclization. In the case of enaminoamides, two nitrogen atoms are possible for coordination (amine group and amide group) of triphenylborane. Our previously studied 
enaminoamides having phenyl at amidic nitrogen (Figure $1, \mathrm{R}^{3}=\mathrm{Ph}$ ) gave products of coordination of triphenylborane with the amine group of enaminoamides (Scheme 5, Path B). Enaminoamides $\mathbf{1}$ described in this paper gave different results. Triphenylborane likely bonded to amidic nitrogen (Scheme 5, Path A), and after protodeboronation and cyclization, the new type of heterocyclic compounds formed. Triazaborinones $\mathbf{5}$ are the main products in most cases. The by-product was mainly diazaborinone. Exceptions are reactions of enaminoamides 1e and 1f, having -CONHMe, and the primary amine group. The behavior of these compounds is similar to that of enaminoamides having -CONHPh studied earlier. Oxazaborines $\mathbf{6 e}$ and $\mathbf{6 f}$, diazaborinones $\mathbf{7 e}$ and $\mathbf{7 f}$, and triazaborine $8 \mathbf{e}$ were isolated when these enaminoamides were used.

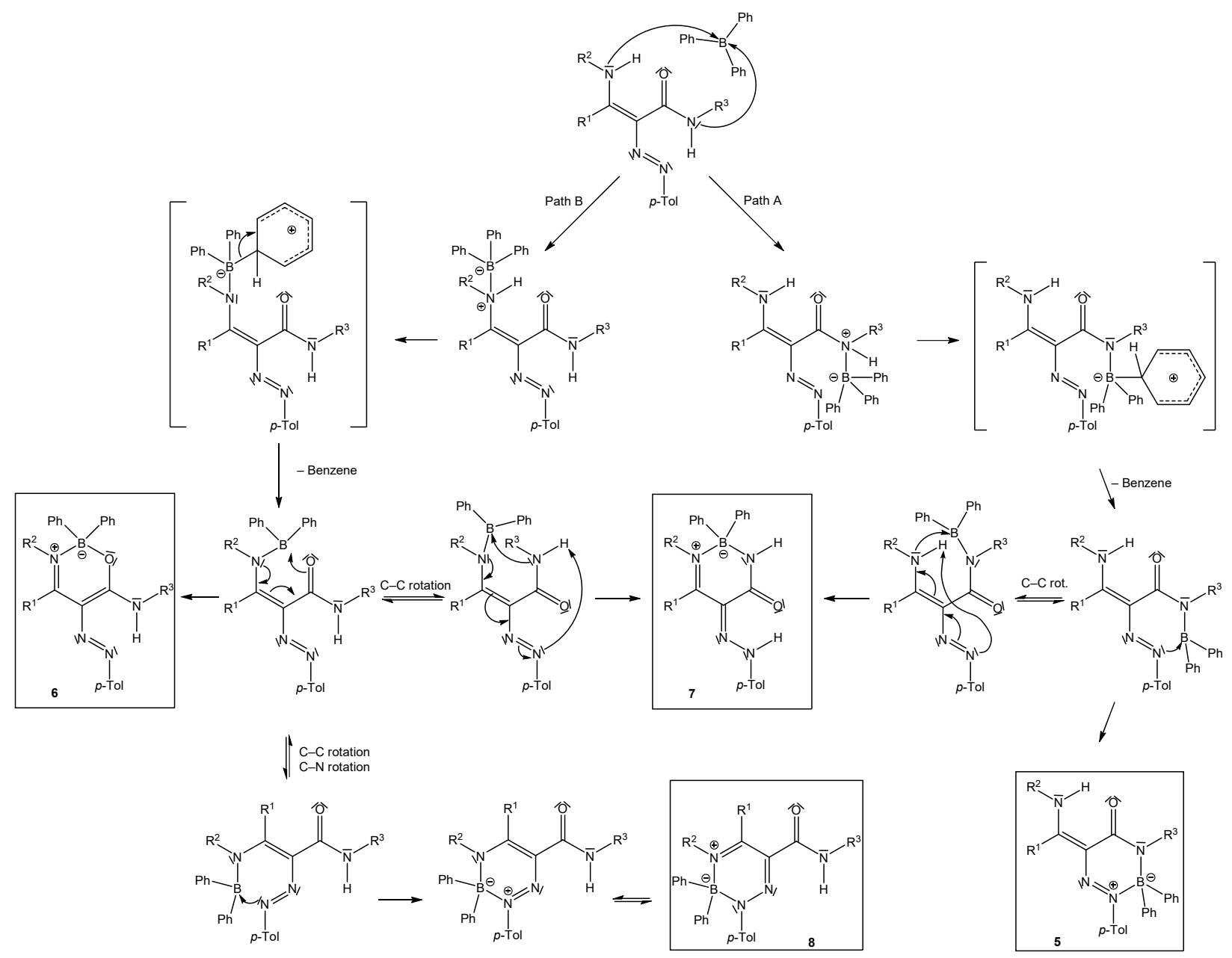

Scheme 5. Suggested mechanism for the reaction of enaminoamides $1 \mathbf{a}-\mathbf{h}$ with 4 -methylbenzenediazonium tetraphenylborate.

Additionally, the products of double coordination of $\mathrm{BPh}_{3}(\mathbf{9 g}$ and $\mathbf{9 h}$, Figure 5) were isolated in the case of the reaction of enaminoamides $\mathbf{1 g}$ and $\mathbf{1 h}$ with diazonium tetraphenylborate carried out in dichloromethane at room temperature (Method A) for $72 \mathrm{~h}$ and $96 \mathrm{~h}$, respectively. The yield was $4 \%$ for $9 \mathrm{~g}$ and $15 \%$ for $9 \mathrm{~h}$. Compound $\mathbf{9 h}$ was also obtained using the Method C (refluxing the mixture for $3 \mathrm{~h}$ ), but the yield was only $3 \%$. Chemical shifts of ${ }^{11} \mathrm{~B}$ and ${ }^{15} \mathrm{~N}$ are similar to those for oxazaborine $\mathbf{6 h}$ and triazaborinone 5h. The study of this type of structure will be the subject of further investigation. 
<smiles></smiles>

9g: $R^{1}=M e$

9h: $\mathrm{R}^{1}=\mathrm{Ph}$

Figure 5. Oxazaborine-triazaborines $9 \mathrm{~g}$ and $9 \mathrm{~h}$.

When oxazaborines $\mathbf{6 a}$ and $\mathbf{6 e}-\mathbf{h}$ were heated at $250{ }^{\circ} \mathrm{C}$ without solvent (Scheme 6), a ring transformation occurred to give the corresponding diazaborinones in good yields (49-82\%). Diazaborinone 7a was not obtained from enaminoamide 1a and diazonium salt, while recyclization gave compound $7 \mathbf{a}$ in $82 \%$ yield. Here is the difference between the previously prepared oxazaborines I (Scheme 2) with the $N$-phenyl group and those in this publication, since only diazaborinones were isolated, and it does not matter what the substitution of the amino group of the starting enaminoamide is.

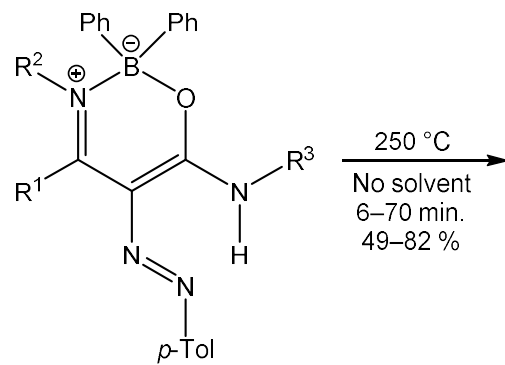

$6 a, 6 e-h$<smiles>[R]C1=NN([R])[B-](c2ccccc2)(c2ccccc2)N([R])C1=O</smiles>

7a.7e-h

Scheme 6. Ring transformation of oxazaborines 6.

NMR parameters such as ${ }^{15} \mathrm{~N}$ and ${ }^{11} \mathrm{~B}$ NMR chemical shifts $(\delta)$ and coupling constants $(J)$ for heterocyclic compounds 5-9 are shown in Table 2.

Table 2. NMR parameters for prepared boron heterocyclic compounds 5-9.

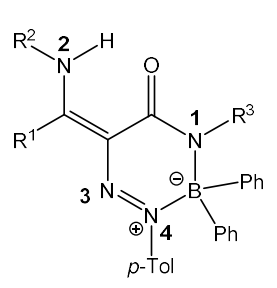

5

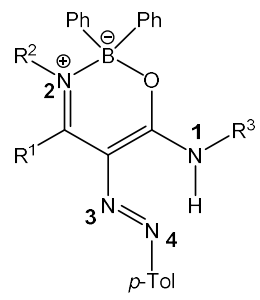

6

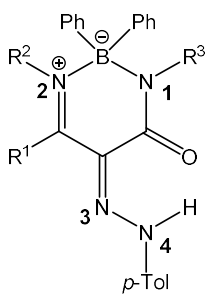

7

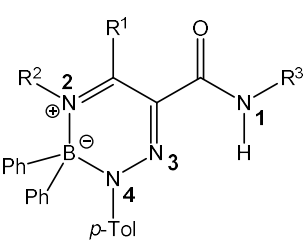

\begin{tabular}{|c|c|c|c|c|c|c|c|c|c|}
\hline Compound & $\mathbf{R}^{1}$ & $\mathbf{R}^{2}$ & $\mathbf{R}^{3}$ & $\delta\left({ }^{15} \mathrm{~N} 1\right)$ & $\delta\left({ }^{15} \mathrm{~N} 2\right)$ & $\delta\left({ }^{15} \mathrm{~N} 3\right)$ & $\delta\left({ }^{15} \mathrm{~N} 4\right)$ & $\delta\left({ }^{11} \mathrm{~B}\right)$ & ${ }^{1} J$ \\
\hline $5 a$ & $\mathrm{Me}$ & $\mathrm{H}$ & $\mathrm{H}$ & -251.5 & -288.7 & 32.0 & -143.8 & 0.99 & $80.0^{a}$ \\
\hline $5 b$ & $\mathrm{Ph}$ & $\mathrm{H}$ & $\mathrm{H}$ & -249.1 & -245.7 & 48.5 & -122.5 & 0.92 & $\begin{array}{l}79.6^{a} \\
88.9^{b} \\
92.0^{b}\end{array}$ \\
\hline $5 c$ & $\mathrm{Me}$ & $\mathrm{Me}$ & $\mathrm{H}$ & -251.5 & -236.4 & 32.5 & -138.4 & 0.42 & $\begin{array}{l}90.5^{\mathrm{a}}, \\
79.4^{\mathrm{b}}\end{array}$ \\
\hline
\end{tabular}


Table 2. Cont.

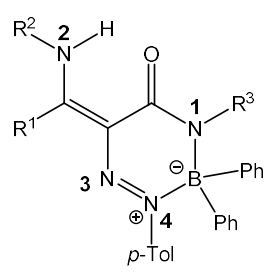

5

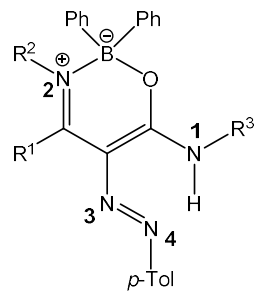

6

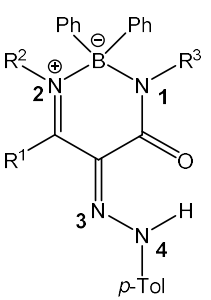

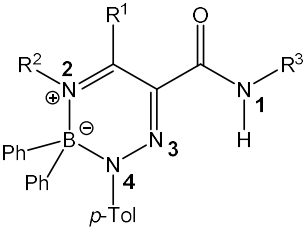

8

\begin{tabular}{|c|c|c|c|c|c|c|c|c|c|}
\hline Compound & $\mathbf{R}^{1}$ & $\mathbf{R}^{2}$ & $\mathbf{R}^{3}$ & $\delta\left({ }^{15} \mathrm{~N} 1\right)$ & $\delta\left({ }^{15} \mathrm{~N} 2\right)$ & $\delta\left({ }^{15} \mathrm{~N} 3\right)$ & $\delta\left({ }^{15} \mathrm{~N} 4\right)$ & $\delta\left({ }^{11} \mathrm{~B}\right)$ & ${ }^{1} J$ \\
\hline $5 d$ & $\mathrm{Ph}$ & $\mathrm{Me}$ & $\mathrm{H}$ & -250.5 & -239.6 & 42.7 & -131.8 & 0.73 & $\begin{array}{l}79.0^{a} \\
88.0^{b}\end{array}$ \\
\hline $5 g$ & $\mathrm{Me}$ & $\mathrm{Me}$ & $\mathrm{Me}$ & -256.4 & -236.1 & 29.6 & -141.9 & 2.06 & $87.9^{b}$ \\
\hline $5 \mathrm{~h}$ & $\mathrm{Ph}$ & $\mathrm{Me}$ & $\mathrm{Me}$ & -254.6 & -238.8 & 39.4 & -133.7 & 2.11 & $87.3^{b}$ \\
\hline $6 a$ & $\mathrm{Me}$ & $\mathrm{H}$ & $\mathrm{H}$ & -278.1 & -222.9 & 85.7 & 21.5 & 2.70 & $\begin{array}{l}89.2^{a}, \\
90.8^{a} \\
79.8^{b}\end{array}$ \\
\hline $6 e$ & $\mathrm{Me}$ & $\mathrm{H}$ & $\mathrm{Me}$ & -273.8 & -224.2 & 82.2 & 8.8 & 2.68 & $90.9^{a}$ \\
\hline $6 f$ & $\mathrm{Ph}$ & $\mathrm{H}$ & $\mathrm{Me}$ & -271.8 & -227.7 & 88.3 & 15.0 & 2.60 & $\begin{array}{l}91.2^{a} \\
82.0^{b}\end{array}$ \\
\hline $6 \mathrm{~g}$ & $\mathrm{Me}$ & $\mathrm{Me}$ & $\mathrm{Me}$ & -274.6 & -221.9 & 79.3 & -1.5 & 4.39 & none \\
\hline $6 \mathrm{~h}$ & $\mathrm{Ph}$ & $\mathrm{Me}$ & $\mathrm{Me}$ & -273.6 & -224.8 & 89.3 & 8.1 & 4.48 & $91.0^{a}$ \\
\hline $7 a$ & $\mathrm{Me}$ & $\mathrm{H}$ & $\mathrm{H}$ & -250.6 & -182.5 & -5.3 & -194.5 & -2.56 & $\begin{array}{l}78.0^{\mathrm{a}}, \\
79.4^{\mathrm{b}}, \\
94.0^{\mathrm{c}}\end{array}$ \\
\hline $7 b$ & $\mathrm{Ph}$ & $\mathrm{H}$ & $\mathrm{H}$ & -250.2 & -184.7 & 2.6 & -190.3 & -2.29 & $\begin{array}{l}77.9^{a}, \\
82.0^{b}, \\
94.5^{c}\end{array}$ \\
\hline $7 \mathrm{c}$ & $\mathrm{Me}$ & $\mathrm{Me}$ & $\mathrm{H}$ & -246.6 & -180.4 & -8.5 & -198.9 & 0.09 & $\begin{array}{l}78.4^{a}, \\
94.1^{c}\end{array}$ \\
\hline $7 d$ & $\mathrm{Ph}$ & $\mathrm{Me}$ & $\mathrm{H}$ & -246.5 & -180.5 & 2.1 & -194.6 & 0.23 & $\begin{array}{l}78.6^{\mathrm{a}}, \\
94.5^{\mathrm{c}}\end{array}$ \\
\hline $7 e$ & $\mathrm{Me}$ & $\mathrm{H}$ & $\mathrm{Me}$ & -252.7 & -179.8 & -9.3 & -197.7 & -0.89 & $93.9^{c}$ \\
\hline $7 f$ & $\mathrm{Ph}$ & $\mathrm{H}$ & $\mathrm{Me}$ & -252.4 & -183.2 & 0.43 & -191.5 & -0.54 & $\begin{array}{l}82.2^{b}, \\
92.2^{c}\end{array}$ \\
\hline $7 \mathrm{~g}$ & $\mathrm{Me}$ & $\mathrm{Me}$ & $\mathrm{Me}$ & -250.0 & -179.5 & -11.4 & -200.6 & 1.30 & $94.0^{c}$ \\
\hline $7 \mathrm{~h}$ & $\mathrm{Ph}$ & $\mathrm{Me}$ & $\mathrm{Me}$ & -250.7 & -179.9 & -0.6 & -196.3 & 1.69 & $94.0^{c}$ \\
\hline $8 \mathbf{e}$ & $\mathrm{Me}$ & $\mathrm{H}$ & $\mathrm{Me}$ & -292.7 & -200.2 & 5.6 & -166.3 & -1.26 & $\begin{array}{l}92.0^{\mathrm{a}} \\
81.0^{\mathrm{b}}\end{array}$ \\
\hline $8 \mathrm{~h}$ & $\mathrm{Ph}$ & $\mathrm{Me}$ & $\mathrm{Me}$ & -292.7 & -200.2 & 4.7 & -169.5 & 1.44 & $92.0^{a}$ \\
\hline $9 g$ & $\mathrm{Me}$ & $\mathrm{Me}$ & $\mathrm{Me}$ & -243.3 & -197.2 & 20.1 & -149.2 & $\begin{array}{l}5.00 \\
2.15 \\
\end{array}$ & none \\
\hline $9 \mathrm{~h}$ & $\mathrm{Ph}$ & $\mathrm{Me}$ & $\mathrm{Me}$ & -243.3 & -198.5 & 27.8 & -144.6 & $\begin{array}{l}5.20 \\
2.00\end{array}$ & none \\
\hline
\end{tabular}

The chemical shifts $\delta$ are reported in ppm, and the coupling constants $J$ in Hertz. ${ }^{a}-{ }^{1} J\left({ }^{15} \mathrm{~N} 1,{ }^{1} \mathrm{H}\right),{ }^{\mathrm{b}}-{ }^{1} J\left({ }^{15} \mathrm{~N} 2,{ }^{1} \mathrm{H}\right)$, ${ }^{\mathrm{c}}-{ }^{1} J\left({ }^{15} \mathrm{~N} 4,{ }^{1} \mathrm{H}\right)$.

\subsection{UV-Visible Spectroscopy}

UV-Vis analyses of the compounds $\mathbf{5 g}, \mathbf{6 g}$, and $\mathbf{7 a}$ in various solvents (cyclohexane, diethyl ether, dichloromethane, tetrahydrofurane, acetonitrile, methanol, formamide) are 
shown in Figure 6 (5g, 7a) and Figure S112 (6g). All absorption spectra for prepared compounds in dichloromethane are listed in the Supplementary Materials (Figures S113-S124). The results of UV-Vis absorption data as an evaluated molar absorption coefficient $(\varepsilon)$ for individual compounds in the solvents used are presented in Tables S1-S4. The dependence of the maximum absorption spectra $\left(\lambda_{\mathrm{MAX}}\right)$ on the solvent properties is not apparent from the above measurements. The possible solvatochromic effects are therefore rather insignificant.

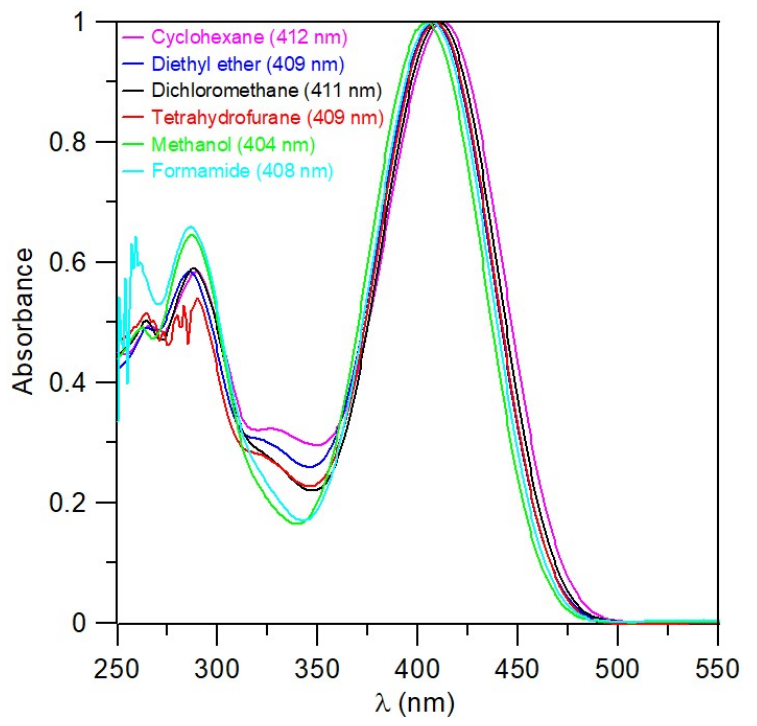

(a)

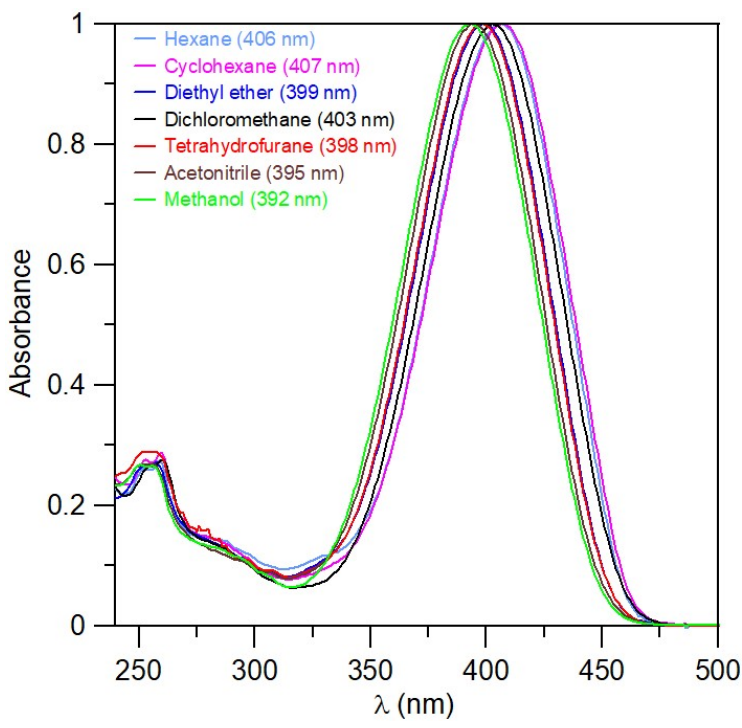

(b)

Figure 6. Normalized UV-Vis spectra of triazaborinone $5 \mathrm{~g}(\mathbf{a})$; and diazaborinone 7a (b).

\subsection{IR Spectroscopy}

The set of measured IR spectra for triazaborinones 5 is depicted in Figure 7, for oxazaborines 6 in Figure 8, for diazaborinones 7 in Figure 9, and for triazaborines 8 and oxazaborine-triazaborines 9 in Figure 10. Weak stretching vibrations of the $\mathrm{C}-\mathrm{H}$ bonds of aromatic benzene rings at $3080-3000 \mathrm{~cm}^{-1}$ are evident in all spectra. Next, it is possible to mention the adjacent $\mathrm{H}-\mathrm{H}$ out-of-plane deformation at the para-substituted ring at $820 \mathrm{~cm}^{-1}$ and several strong vibrations of the monosubstituted benzene ring, the out-of-plane ring bending at $706 \mathrm{~cm}^{-1}$, and the adjacent $\mathrm{H}-\mathrm{H}$ out-of-plane deformation at $746 \mathrm{~cm}^{-1}$.

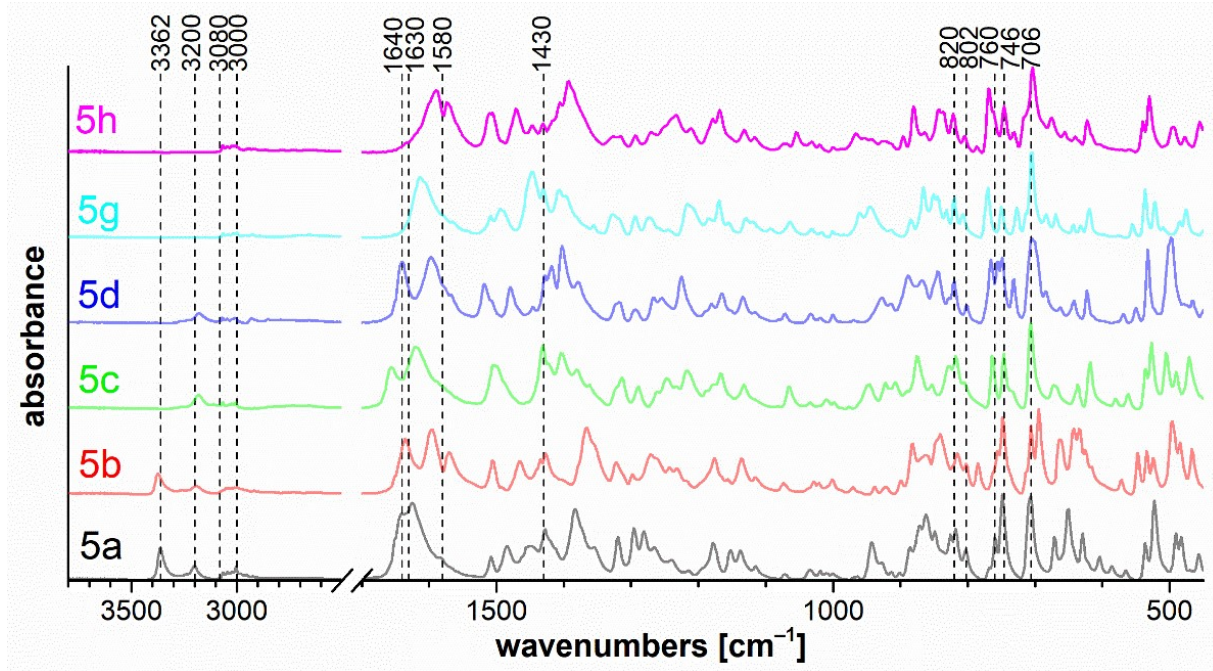

Figure 7. FTIR ATR spectra of triazaborinones $5 a-d, 5 g, 5 h$. 


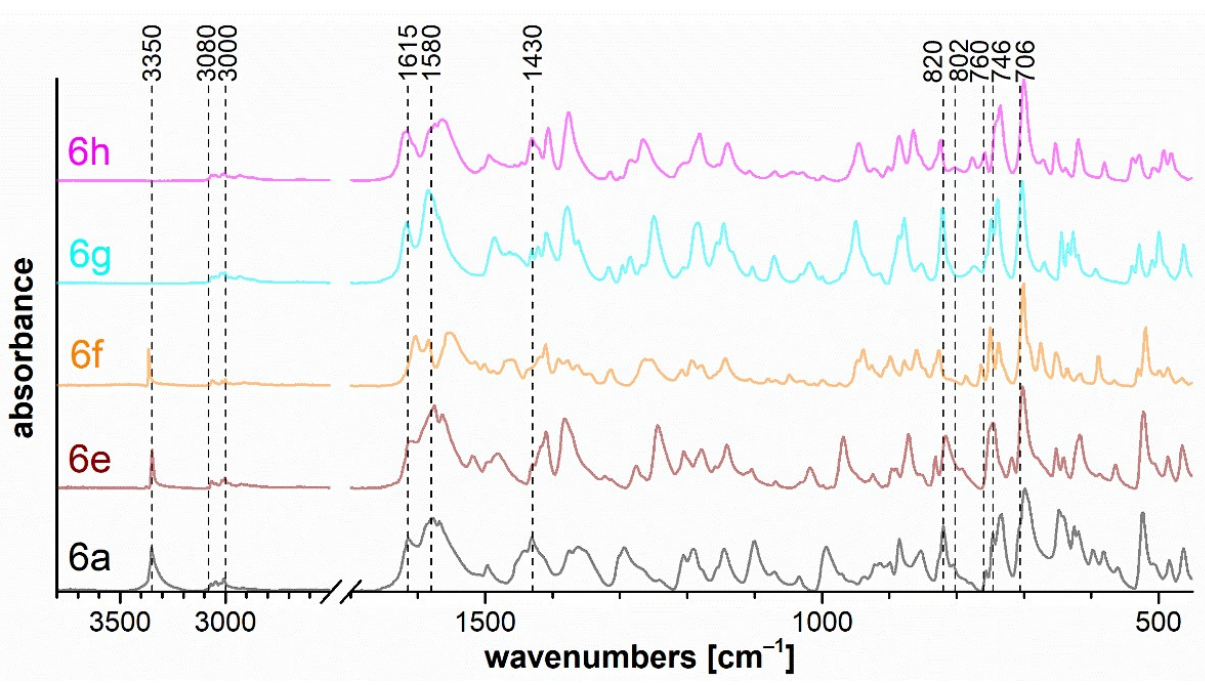

Figure 8. FTIR ATR spectra of oxazaborines $6 \mathbf{a}, \mathbf{6 e -}-\mathbf{h}$.

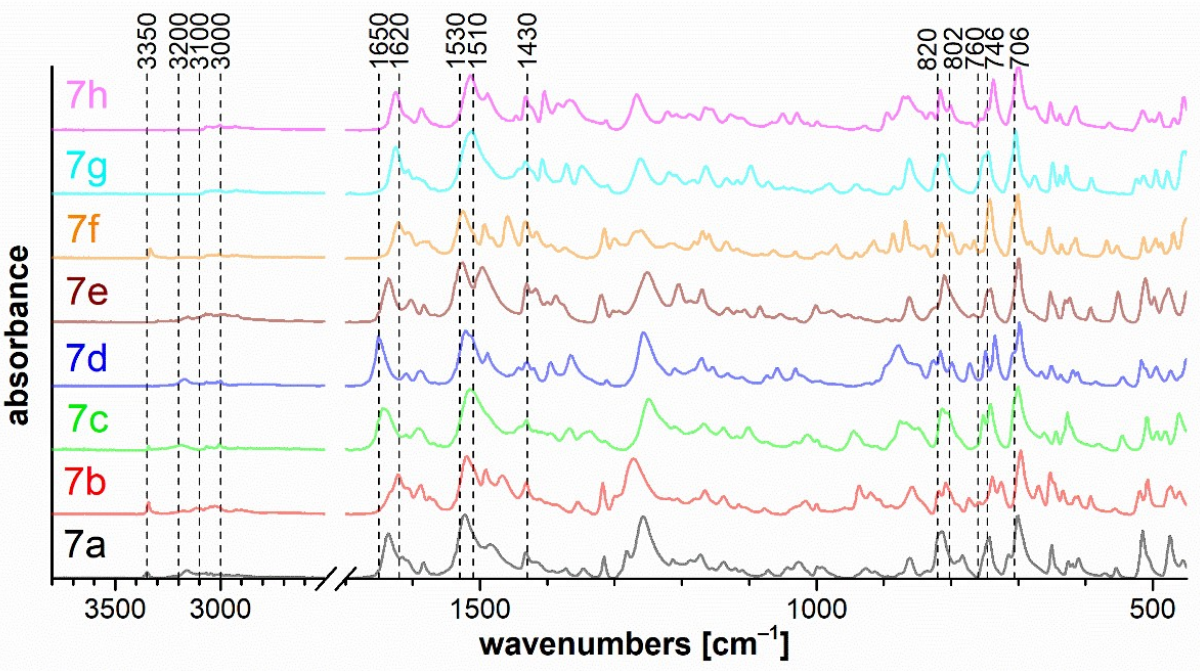

Figure 9. FTIR ATR spectra of diazaborinones $7 \mathbf{a}-\mathbf{h}$.

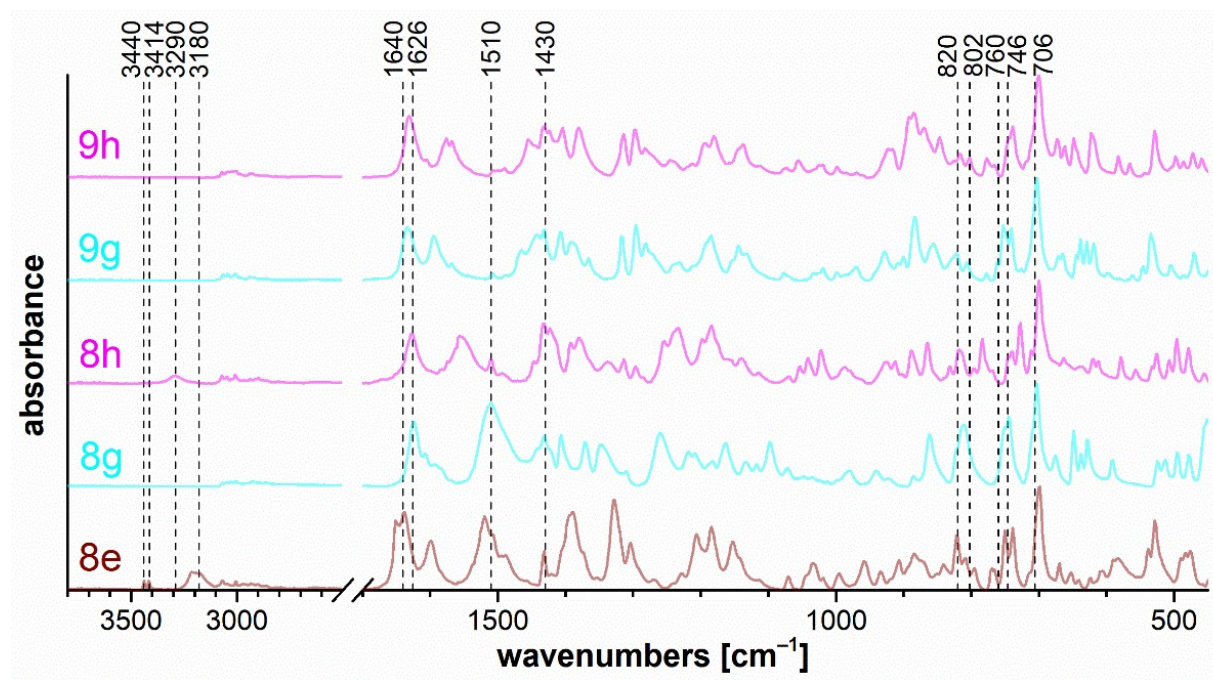

Figure 10. FTIR ATR spectra of triazaborines $8 \mathrm{e}, \mathbf{8 g}$, and $8 \mathrm{~h}$, and oxazaborine-triazaborines $\mathbf{9 g}$ and $9 h$. 
IR spectra $\mathbf{5 a}$ and $\mathbf{5 b}$ show the stretching vibration of the primary amino group at $3362 \mathrm{~cm}^{-1}$. The stretching vibration of the $\mathrm{N}-\mathrm{H}$ and $\mathrm{C}=\mathrm{O}$ groups in the cis configuration is evident for spectra $5 \mathbf{a}-\mathbf{d}$ at 3200 and $1640 \mathrm{~cm}^{-1}$, respectively. Strong stretching vibrations of the $\mathrm{C}=\mathrm{O}$ of $\alpha, \beta$-unsaturated $\beta$-amino-substituted imide are located in the $1630-1580 \mathrm{~cm}^{-1}$ region. In this case, the effect of substitution on the double bond is evident. The methylsubstituted $\left(\mathrm{R}^{1}=\mathrm{Me}\right)$ compounds $\mathbf{5 a}, \mathbf{5} \mathbf{c}$, and $\mathbf{5 g}$ are shifted to higher wavenumbers than the phenyl-substituted $\left(\mathrm{R}^{1}=\mathrm{Ph}\right)$ compounds $\mathbf{5 b}, \mathbf{5 d}$, and $5 \mathbf{h}$. The sharp band caused by the vibration of the ring at $1430 \mathrm{~cm}^{-1}$ is characteristic of compounds containing a B-phenyl bond. The ring C-H out-of-plane deformation for phenyl-substituted boron at $760 \mathrm{~cm}^{-1}$ is present as a shoulder. Two phenyl groups should appear as a doublet with a $20 \mathrm{~cm}^{-1}$ separation. These bands can be overlayed by the adjacent $\mathrm{H}-\mathrm{H}$ out-of-plane deformation at $746 \mathrm{~cm}^{-1}$, as mentioned above.

Figure 8 shows the band at $3350 \mathrm{~cm}^{-1}$, which corresponds to the free N-H stretching of the imine bound to the oxazaborine ring. This is consistent with the fact that this vibration occurs only for compounds $\mathbf{6 a}, \mathbf{6 e}$, and $\mathbf{6 f}$. In the case of $\mathbf{6 a}$, this band is broadened due to the stretching vibration of the primary amino group.

The bands of the $\mathrm{N}-\mathrm{H}$ stretching vibrations of the imine bonded to the diazaborinone ring at $3350 \mathrm{~cm}^{-1}$ for $\mathbf{7 a}, \mathbf{7 b}, \mathbf{7 e}$, and $\mathbf{7 f}$ are shown in Figure 9. The stretching vibration of the $\mathrm{N}-\mathrm{H}$ (spectra $\mathbf{7 a}-\mathbf{d}$ ) and $\mathrm{C}=\mathrm{O}$ (spectra $\mathbf{7 a}-\mathbf{h}$ ) groups in the cis configuration is evident in the range of 3200-3100 $\mathrm{cm}^{-1}$ and $1650-1620 \mathrm{~cm}^{-1}$, respectively. The spectra of all diazaborinones $7 \mathbf{a}-\mathbf{h}$ contain very strong bands in the $1530-1510 \mathrm{~cm}^{-1}$ region, corresponding to an arrangement of atoms in a hydrazoketones $\left(\mathrm{R}^{1}-\mathrm{CO}-\mathrm{CR}^{2}=\mathrm{N}-\mathrm{NH}-\right)$. For oxazaborines 6. Figure 8 shows two strong absorption bands-one at approximately $1615 \mathrm{~cm}^{-1}$ and another more intense near $1580 \mathrm{~cm}^{-1}$ —due to vibrations of the conjugated system of the unsaturated double bond with the aromatic diazo group.

Triazaborine 8e (Figure 10) shows bands at 3440 and $3414 \mathrm{~cm}^{-1}$, which correspond to the free $\mathrm{N}-\mathrm{H}$ stretching of imine bonded to the triazaborine ring. The stretching vibration of the $\mathrm{N}-\mathrm{H}$ and $\mathrm{C}=\mathrm{O}$ groups in the cis configuration is evident for spectra $\mathbf{8 e}$ and $\mathbf{8 h}$ in the range of $3290-3180 \mathrm{~cm}^{-1}$ and $1640-1626 \mathrm{~cm}^{-1}$, respectively. The position of these bands is affected by methyl- or phenyl-substitution adjacent to the amide. The sharp band caused by the ring vibration at $1430 \mathrm{~cm}^{-1}$ is characteristic of compounds containing a B-phenyl bond and is evident in all cases in the Figure 10. The spectra of triazaborines $\mathbf{8 g}$, $\mathbf{8 e}$, and $\mathbf{8 h}$ contain very strong bands at $1510 \mathrm{~cm}^{-1}$, which corresponds to an arrangement of atoms in a hydrazoketones $\left(\mathrm{R}^{1}-\mathrm{CO}-\mathrm{CR}^{2}=\mathrm{N}-\mathrm{NH}-\right)$.

The other selected absorption bands in Figures 8-10 are analogous to those in Figure 7 and are described above.

\subsection{X-ray}

For compounds $\mathbf{5 c}, \mathbf{5 d}, \mathbf{5 g}, \mathbf{6 a}, \mathbf{6 e}$, and $\mathbf{7 f}$, we were able to prepare crystals suitable for single-crystal X-ray diffraction. The results are summarized in Table S5.

Triazaborinone $5 c$ contains two types of hydrogen bonds. The first intramolecular bond is located between the N1 and O1 atoms. The other two intermolecular hydrogen bonds between $\mathrm{N} 4$ from the first molecule and $\mathrm{O} 1$ from the second molecule and vice versa bind the dimer-forming molecules. See Figure 11a for details. The plane passing through the atoms forming these intermolecular hydrogen bonds is shown in this Figure. The center of gravity of all dimer atoms is in the center of the hydrogen bond system. The point is marked as a centroid. The periodic arrangement of these basic dimers in the crystal is shown in Figures S125-S127 in the Supplementary Material. The view in the direction of the crystallographic axis $a$ and $c$, and the reciprocal cell axis $b^{*}$ is shown. The conjugate system of three double bonds (between O1 and C1, C2 and N2, and N1 and C3 in one molecule) lies in a plane. The analogous plane from the second molecule of the dimer is parallel to the first plane and is shifted by $0.128 \AA$, as can be seen in Figure S128. Thus, all of these double bonds in the dimer lie practically in the plane. These bonds were assigned as doubles on the basis of their lengths, and the fact that they lie in a plane supports the 
indicated structure with a lower application of conjugation between the triazaborinone ring and the aromatic ring. The aromatic benzene rings are deflected out of these planes as well as boron atoms.

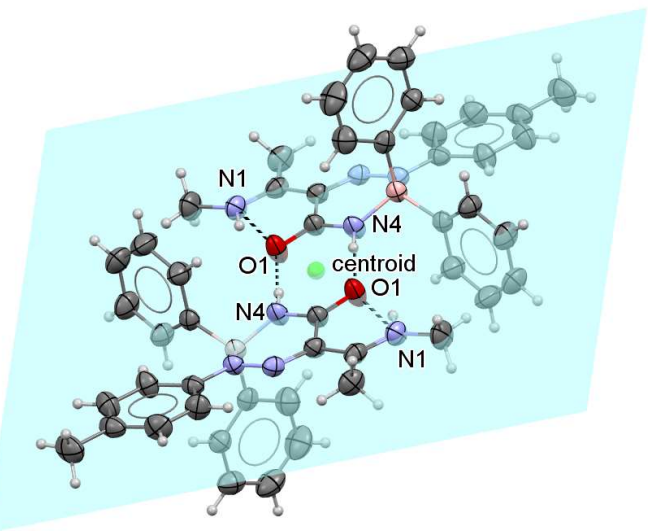

(a)

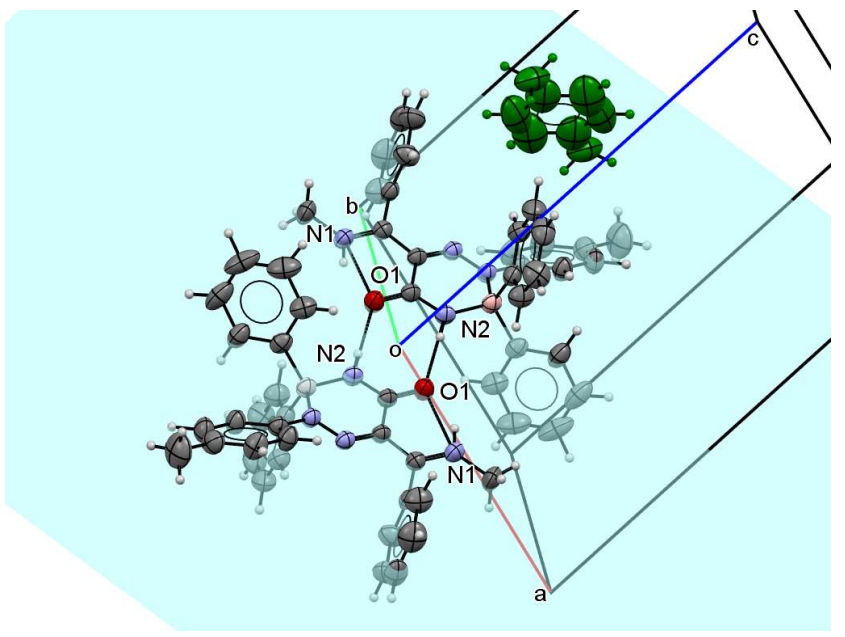

(b)

Figure 11. ORTEP diagram of the dimer forming the basis of the triazaborinone 5 c crystal (a); and ORTEP diagram of the triazaborinone $\mathbf{5 d}$ crystal (b).

Triazaborinone $\mathbf{5 d}$ forms dimers such as $\mathbf{5 c}$. The structure of the dimer is shown in Figure $11 \mathrm{~b}$. As in the previous case, the dimer molecule is symmetric according to the center of symmetry, which in this case is at the beginning of the coordinates of the unit cell. By replacing the methyl group bound to carbon $\mathrm{C} 3$ with a phenyl group, hydrophobic cavities are formed in the structure of triazaborinone $\mathbf{5 d}$ in which toluene is enclosed as a solvent, one molecule of toluene stoichiometrically per dimer $\mathbf{5 d}$. The toluene molecule is captured in the middle of the $b c$ side of the crystallographic unit cell and is green-colored for clarity. The toluene molecule is located freely in the cavity. The presence of a toluene methyl group on two sides is a disorder for statistical reasons. Similar host-guest structures have been previously described by us for 3-amino-2-(4-dimethylaminophenyldiazenyl)-1-phenylbut-2-en-1one (reaction of 3-amino-1-phenylbut-2-en-1-one with 4-dimethylaminobenzenediazonium tetrafluoroborate) [34]. The arrangement of the molecules in the crystal is shown in Figures S129 and S130. The hydrogen bonds that form the dimers are again shown in the figures for easier orientation.

Triazaborinone $\mathbf{5 g}$ has a similar arrangement of double bonds lying in the plane as triazaborinone 5c. The ORTEP diagram is shown in Figure 12a. Because of the substitution of imide hydrogen on the triazaborinone ring with a methyl group, triazaborinone $5 \mathrm{~g}$ cannot form intramolecular hydrogen bonds leading to dimers. In this case, the crystal structure is formed by individual molecules that are bound together by weak nonbonding interactions, e.g., between aromatic rings. This arrangement is shown in Figure S131. The interaction mentioned can be seen in the middle of an indicated crystallographic unit cell. These phenyl groups attached to the boron atom form graphite-like $\pi-\pi$ stacking with a distance between these rings of $3.293 \AA$. The chains formed by this layering in the direction of the crystallographic axis $b$ are repeated regularly in the directions of the crystallographic axes $a$ and $c$. The planes indicated in the figure are those in which the conjugated double bonds between the atoms $\mathrm{C} 1=\mathrm{O} 1, \mathrm{C} 2=\mathrm{N} 2$, and $\mathrm{C} 3=\mathrm{N} 4$ lie. All atoms of the triazaborinone ring of compound $5 \mathrm{~g}$ lie in the plane from which the ring of the $p$-tolyl group is slightly turned out. 


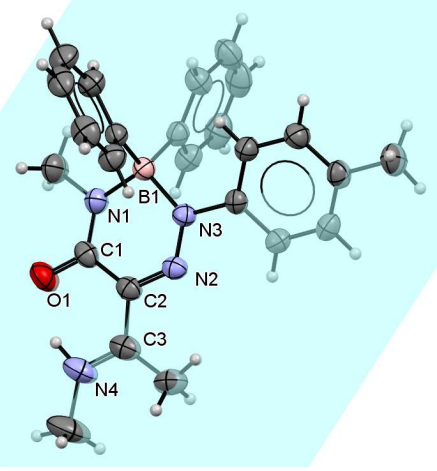

(a)

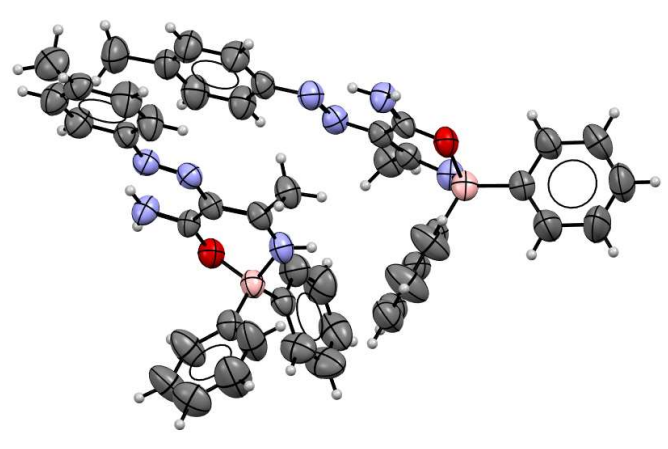

(b)

Figure 12. ORTEP diagram of the triazaborinone $5 \mathrm{~g}$ crystal (a); and ORTEP diagram of the oxazaborine $6 \mathbf{a}$ crystal (b).

Oxazaborine 6a, which was previously prepared from 3-aminobut-2-ennitrile as the starting compound, was characterized in our previous publication [30]. Unlike our earlier publication, the prepared single crystal 6a was now measured at room temperature. The structure obtained is identical, and the newly estimated values are given in Table S5. The new parameters slightly differ from those previously published due to the measurement temperature, and the resulting statistics are slightly better. Unlike other prepared single crystals at this work, only oxazaborine 6a needs two molecules to form an asymmetric unit (see Figure 12b or Figure S132). In addition, in the case of this substance, three conjugated double bonds lie in the plane. They are $\mathrm{N} 3=\mathrm{N} 4, \mathrm{C} 1=\mathrm{C} 2$, and $\mathrm{C} 3=\mathrm{N} 2$. In this case, the boron atoms are completely deflected out of these planes, and the $\mathrm{N}-\mathrm{B}-\mathrm{O}$ angles are $103.69^{\circ}$ and $104.13^{\circ}$. Sizes of such angles are not common but are described in the literature.

Oxazaborine $6 \mathbf{e}$ differs from previously published $\mathbf{6 a}$ by substituting the hydrogen atom of the amide with a methyl group. Although the structure of oxazaborine 6 a consists of dimers due to hydrogen bonds similar to the structure of triazaborinone $5 \mathrm{c}$ described above, the formation of such dimers in the structure of oxazaborine $6 \mathbf{e}$ is not possible. The oxygen atom $\mathrm{O} 1$ in compound 6 e does not participate in the formation of any hydrogen bond. In this case, the entire oxazaborine ring lies in the plane, as well as the $p$-tolyl group bonded to nitrogen N4. Benzene rings attached to a boron atom outside this plane form a roughly tetragonal system. The ORTEP diagram of this compound shows Figure 13a. The crystal structure of oxazaborine $\mathbf{6 e}$ is formed by chains of individual molecules bound to each other by $\pi-\pi$ interactions. These interactions in the direction of the crystallographic axis $c$ are shown in Figure S133. Figure S134 shows the alternation of these chains in the direction of the crystallographic axes $a$ and $c$.

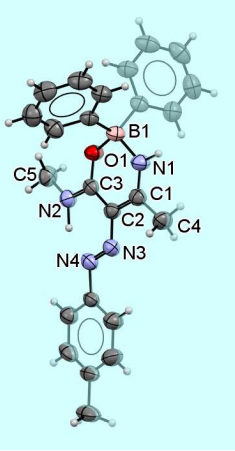

(a)

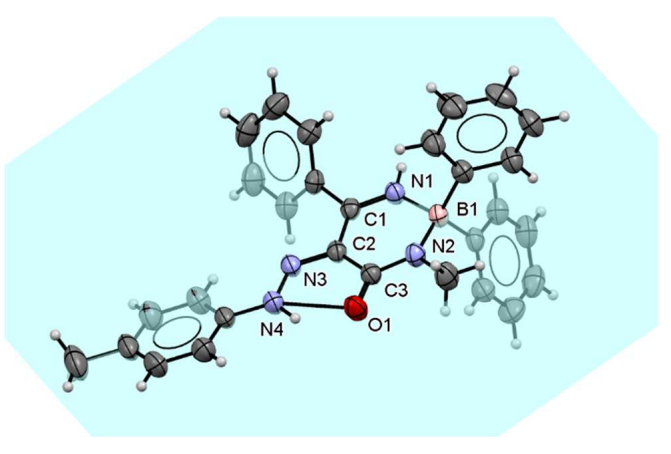

(b)

Figure 13. ORTEP diagram of the oxazaborine 6 e crystal (a); and ORTEP diagram of the diazaborinone $7 f$ crystal (b). 
The ORTEP diagram of the diazaborinone $\mathbf{7 f}$ is shown in Figure $13 \mathrm{~b}$. Two similar diazaborinones have been previously published [28]. The first differs by the substitutions on the $\mathrm{C} 1$ and $\mathrm{N} 2$ atoms, where the substituents are exchanged. The second differs by the substitution on the N2 atom, where the phenyl group is replaced by a methyl group. In the structures described previously, the formation of chains of individual molecules was observed due to the short distance interaction between the oxygen atom $\mathrm{O} 1$ and the imine hydrogen bonded to the nitrogen atom $\mathrm{N} 1$ of the second molecule. In the case of the newly described structure of diazaborinone $\mathbf{7 f}$, such an intermolecular hydrogen bond does not occur, and only weak interactions occur between the molecules in a crystal. The crystal packing in the direction of the crystallographic axes $a$ and $b$ is shown in Figures S135 and S136. The first interaction is a $\pi-\pi$ stacking between the $p$-tolyl groups. These interactions lie on the $a b$ side of the crystallographic unit cell. The second interaction is between phenyl groups bonded to boron atoms. These groups form layers that are nested inside each other. These interactions lie in the center plane of the crystallographic unit cell in one-half of the edge length $c$.

\subsection{Fluorescence}

Some substances showed visible fluorescence when irradiated with a UV lamp (366 nm). This was found during thin-layer chromatography with UV detection. Therefore, steadystate photoluminescence measurements in the solid state were performed for a series of triazaborinones $\mathbf{5 a}-\mathbf{d}, \mathbf{5 g}$, and $\mathbf{5 h}$; diazaborinones $\mathbf{7 a}$ and $\mathbf{7 f}-\mathbf{g}$; triazaborine $\mathbf{8 h}$; and several previously prepared substances. The measured substances were excited by radiation at a wavelength of $360 \mathrm{~nm}$, and the corresponding spectra are shown in Figures 14 and 15.

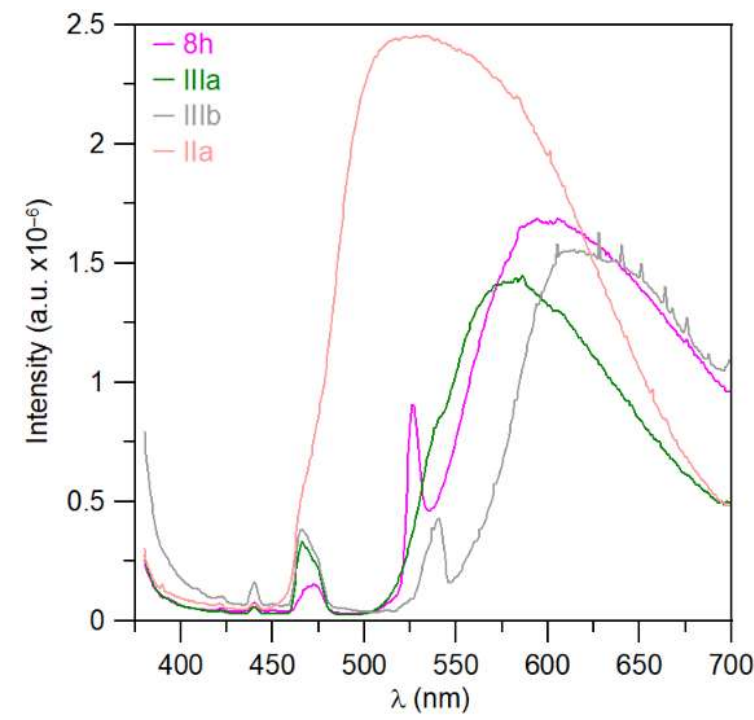

Figure 14. Fluorescence spectra of triazaborine $\mathbf{8 h}$ and previously prepared diazaborinone IIa (Scheme 2, $\mathrm{R}^{1}=\mathrm{Me}, \mathrm{R}^{2}=\mathrm{H}$ ) and triazaborines IIIa (Scheme 2, $\mathrm{R}^{1}=\mathrm{Me}, \mathrm{R}^{2}=\mathrm{H}$ ) and IIIb (Scheme 2, $\left.\mathrm{R}^{1}=\mathrm{Ph}, \mathrm{R}^{2}=\mathrm{Me}\right)$.

Time-resolved photoluminescence measurements were also performed, and quantum yields were evaluated. Unfortunately, measurable quantum yields were observed for only three substances. Fluorescence quantum yields values are not very high. The quantum yield for triazaborinone $5 \mathrm{~h}$ is $3.84 \% \pm 1 \%$, for triazaborinone $5 \mathrm{~g} 4.08 \% \pm 1 \%$, and for diazaborinone $7 \mathrm{a} 14.62 \% \pm 1 \%$. The absorption and emission spectra for these substances are shown in Figures S137-139. 


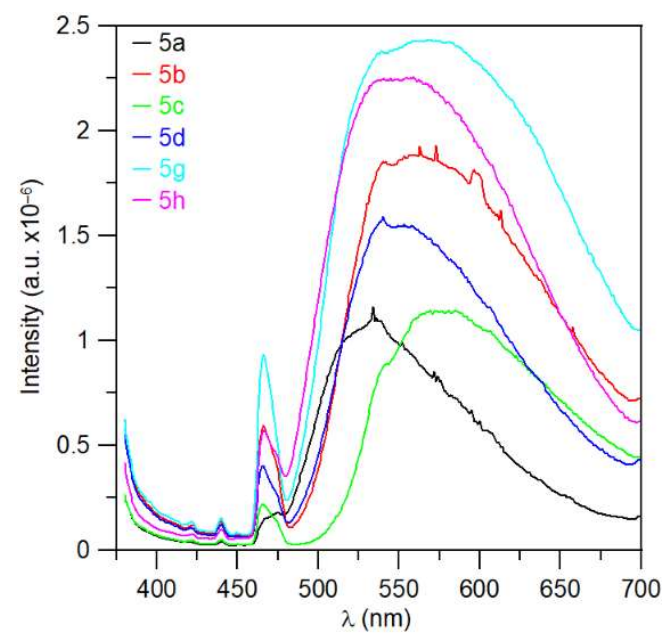

(a)

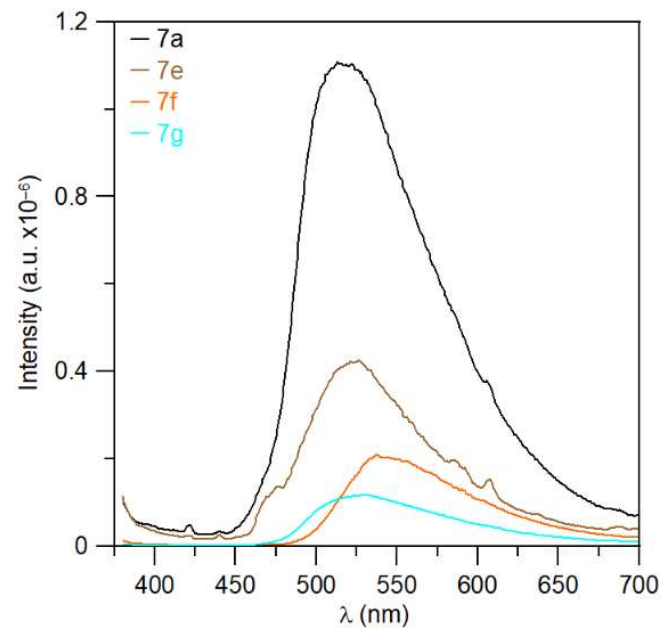

(b)

Figure 15. Fluorescence spectrum: (a) triazaborines $5 \mathbf{a}-\mathbf{d}, \mathbf{5 g}$, and $5 \mathbf{h}$; and (b) diazaborinones $7 \mathbf{a}$, $7 f-g$.

\section{Experimental}

\subsection{Materials and Methods}

All chemicals and dried dichloromethane except those mentioned below were purchased from commercial suppliers (Acros Organics (Part of Thermo Fisher Scientific, Geel, Belgium)), Sigma-Aldrich (Merck, Darmstadt, Germany), or Fluorochem (Hadfield, Derbyshire, UK). Toluene and diethylether were dried over sodium.

NMR spectra were measured in $\mathrm{CDCl}_{3}$ or in DMSO- $d_{6}$ using a Bruker AVANCE III 400 spectrometer (Ettlingen, Germany) operating at $400 \mathrm{MHz}\left({ }^{1} \mathrm{H}\right)$ and $100 \mathrm{MHz}\left({ }^{13} \mathrm{C}\right)$ or using a Bruker Ascend 500 spectrometer (Ettlingen, Germany) operating at $500 \mathrm{MHz}\left({ }^{1} \mathrm{H}\right)$, $125 \mathrm{MHz}\left({ }^{13} \mathrm{C}\right), 160 \mathrm{MHz}\left({ }^{11} \mathrm{~B}\right)$, and $50 \mathrm{MHz}\left({ }^{15} \mathrm{~N}\right)$. All of the pulse sequences were taken from the Bruker software library. The ${ }^{13} \mathrm{C}$ NMR spectra were measured in a standard way and by means of the APT pulse sequence. The data are reported as follows: chemical shift in ppm ( $\delta)$, multiplicity ( $\mathrm{s}=$ singlet, $\mathrm{d}=$ doublet, $\mathrm{q}=$ quartet, $\mathrm{m}=$ multiplet, br $\mathrm{s}=$ broad singlet, br q = broad quartet). The coupling constants $J$ are reported in Hertz (Hz). TMS was used as an internal standard for ${ }^{1} \mathrm{H} \mathrm{NMR}$ in $\mathrm{CDCl}_{3}(\delta 0.00) . \mathrm{CDCl}_{3}$ was used as an internal standard for ${ }^{13} \mathrm{C}$ NMR (the middle signal, $\left.\delta 77.16\right)$. $\mathrm{B}(\mathrm{OMe})_{3}$ was used as an external standard for ${ }^{11} \mathrm{~B}$ NMR $(\delta 18.1)$. Nitromethane was used as an external standard for ${ }^{15} \mathrm{~N}$ NMR ( $\delta 0.00)$. DMSO- $d_{6}$ was used as an internal standard for both ${ }^{1} \mathrm{H}$ NMR (the middle signal $\delta 2.55$ ) and ${ }^{13} \mathrm{C}$ NMR (the middle signal $\delta 39.6$ ).

Elemental analyses were performed on a Flash 2000 CHNS Elemental Analyzer (Thermo Fisher Scientific, Milan, Italy).

Melting points were measured on a Kofler Boetius PHMK 80/2644 hot-stage microscope and were not corrected.

High-resolution mass spectra were recorded on a MALDI LTQ Orbitrap XL (Thermo Fisher Scientific, Bremen, Italy) equipped with a nitrogen UV laser $(337 \mathrm{~nm}, 60 \mathrm{~Hz}, 8-20 \mu \mathrm{J})$ in the positive ion mode. For the CID experiment using the linear trap quadrupole (LTQ) helium was used as the collision gas and 2,5-dihydroxybenzoic acid (DHB) as the MALDI matrix.

UV-Vis spectra were recorded on a UV-Vis spectrophotometer Hewlett-Packard 8453 (Waldbronn, Germany). IR spectra were recorded on a Nicolet iS50 (Madison, Wisconsin, USA) equipped with an ATR diamond crystal (neat solid samples). The wavenumber range 2500-1700 $\mathrm{cm}^{-1}$ was excluded due to diamond absorption. The spectra were processed with the SPECTRAGRYPH 1.2.15 (Dr. Friedrich Menges, Oberstdorf, Germany).

Steady-state and time-resolved PL measurements were performed based on a multifunctional spectrometer with L-geometry of excitation-detection pathways (FluoTime 300, PicoQuant, Berlin, Germany). A Xenon arc lamp and a PMT were used as the excitation 
sources and detectors for PL experiments. The PL-QY value could be obtained based on the spectrometer incorporated with an integrating sphere. Excitation wavelength: $360 \mathrm{~nm}$. Range: 340-700 nm.

Crystal data for all compounds were collected at $295 \mathrm{~K}$ using a Nonius Kappa CCD diffractometer with graphite monochromated Mo-K $\alpha$ radiation $(\lambda=0.71073 \AA$ A $)$. The data sets were integrated with the Denzo SMN package [35] and corrected for Lorentz, polarization, and absorption effects (SORTAV) [36]. Structures were solved by direct methods using the SIR97 [37] system of programs and refined anisotropically by using full-matrix least-squares for all non-hydrogen atoms and hydrogen atoms included on their calculated positions, riding on their carrier atoms, except the $\mathrm{N}-\mathrm{H}$ hydrogens forming intramolecular hydrogen bonds, which were refined isotropically. All calculations were performed by using SHELXL 2014/6 [38], PARST [39] and PLATON [40] implemented in the WINGX [41] system of programs. Visualization of structures was done with MERCURY 2020.2.0.

\subsection{Synthetic Procedure}

3-Aminobut-2-enamide (1a). The dry ammonia gas was bubbled into a mixture of 3oxobutanamide (4a) $(10.1 \mathrm{~g}, 100 \mathrm{mmol})$ and diethyl ether $(20 \mathrm{~mL})$ over a period of $1 \mathrm{~h}$. Then liquid ammonia $(15 \mathrm{~mL})$ was added and the mixture was stirred at room temperature overnight. The crystals were filtered off and boiled in chloroform $(30 \mathrm{~mL})$ for $5 \mathrm{~min}$. After cooling, the white crystals were filtered off. Yield $7.13 \mathrm{~g}(71 \%)$, m.p. 95.5-99 ${ }^{\circ} \mathrm{C}$ (Ref. [42] 98-100 $\left.{ }^{\circ} \mathrm{C}\right) .{ }^{1} \mathrm{H}-\mathrm{NMR}\left(\mathrm{DMSO}-d_{6}, 500 \mathrm{MHz}\right): \delta 7.31$ (br s, 2H), 6.45 (br s, 1H), 6.09 (br s, 1H), 4.35 (s, 1H), 1.76 (s, 3H); ${ }^{13} \mathrm{C}-\mathrm{NMR}$ (DMSO-d $\left.d_{6} 125 \mathrm{MHz}\right): \delta 172.6,157.0,85.4,25.7,21.8$.

3-Amino-3-phenylprop-2-enamide (1) $)$. The solution of ethyl 3-oxo-3-phenylpropanoate $(22.1 \mathrm{~g}, 115 \mathrm{mmol})$ and $25 \%$ aq. ammonia $(22.7 \mathrm{~mL}, 300 \mathrm{mmol})$ was heated with stirring in an Ace pressure tube at $130{ }^{\circ} \mathrm{C}$ (oil bath) for $4.5 \mathrm{~h}$. After cooling, the solid product was filtered off. Yield $6.6 \mathrm{~g}$. The filtrate was concentrated and then aq. ammonia $(16 \mathrm{~mL})$ was added and heated in an Ace pressure tube at $130^{\circ} \mathrm{C}$ for $3 \mathrm{~h}$. After cooling, the solid product was filtered off. Yield $1.5 \mathrm{~g}$. Yellowish crystal, total yield $8.1 \mathrm{~g}(43 \%), \mathrm{m} . \mathrm{p} .162-164.5^{\circ} \mathrm{C}$ (Ref. [16] $\left.164{ }^{\circ} \mathrm{C}\right) .{ }^{1} \mathrm{H}-\mathrm{NMR}$ (DMSO-d $\left.{ }_{6}, 400 \mathrm{MHz}\right): \delta 7.58-7.60(\mathrm{~m}, 2 \mathrm{H}), 7.46-7.48(\mathrm{~m}, 3 \mathrm{H})$, 6.85 (br s, 1H), 6.26 (br s, $1 \mathrm{H}), 4.91$ (s, $1 \mathrm{H}) ;{ }^{13} \mathrm{C}-\mathrm{NMR}$ (DMSO-d $6,100 \mathrm{MHz}$ ): $\delta 172.2,157.1$, $137.9,129.6,128.6,126.1,85.9$.

3-(Methylamino)but-2-enamide (1c). 3-Oxobutanamide (4a) (5 g, $50 \mathrm{mmol}$ ) and methylamine solution (33 wt.\% in absolute ethanol, $18.5 \mathrm{~mL}, 150 \mathrm{mmol}$ ) were heated in an Ace pressure tube for $4 \mathrm{~h}$ at $130-140^{\circ} \mathrm{C}$. After cooling to room temperature, ethanol was evaporated, and the oil was cooled. Ethyl acetate $(5 \mathrm{~mL})$ was added, and the mixture was stirred for $5 \mathrm{~min}$ at cooling. The crystals were filtered off, and the filtrate was evaporated. Ethyl acetate $(3 \mathrm{~mL})$ was added to the filtrate and the mixture was stirred for $5 \mathrm{~min}$ at cooling. The crystals were filtered off. This compound must be stored in the refrigerator. Total yield $3.33 \mathrm{~g} \mathrm{(58 \% ),} \mathrm{m.p.} 70-74{ }^{\circ} \mathrm{C} .{ }^{1} \mathrm{H}-\mathrm{NMR}\left(\mathrm{CDCl}_{3}, 400 \mathrm{MHz}\right): \delta 8.99$ (br s, $\left.1 \mathrm{H}\right), 5.01$ (br s, $\left.2 \mathrm{H}\right)$, $4.37(\mathrm{~s}, 1 \mathrm{H}), 2.87(\mathrm{~d}, J=5.3 \mathrm{~Hz}, 3 \mathrm{H}), 1.87(\mathrm{~s}, 3 \mathrm{H}) ;{ }^{13} \mathrm{C}-\mathrm{NMR}\left(\mathrm{CDCl}_{3}, 100 \mathrm{MHz}\right): \delta 173.0,161.0$, 83.1, 29.3, 19.1. HR-MS (MALDI), cald. for $\mathrm{C}_{5} \mathrm{H}_{11} \mathrm{~N}_{2} \mathrm{O}$ : $[\mathrm{M}+\mathrm{H}]^{+}$115.0866, found: 115.0867 $[\mathrm{M}+\mathrm{H}]^{+}$.

3-(Methylamino)-3-phenylprop-2-enamide (1d). The solution of 3-oxo-3-phenylprop-2enamide (4b) $(3.2 \mathrm{~g}, 19.6 \mathrm{mmol})$ and $33 \mathrm{wt} \%$ methylamine in ethanol $(7.4 \mathrm{~mL}, 58.8 \mathrm{mmol})$ was heated with stirring in an Ace pressure tube at $135-140{ }^{\circ} \mathrm{C}$. After heating for $4 \mathrm{~h}$, ethanol was evaporated under reduced pressure. Ethyl acetate $(5 \mathrm{~mL})$ was added to the viscous oil and the mixture was heated for $2 \mathrm{~min}$. After cooling, the light-yellow crystals were filtered off. Yield $2.8 \mathrm{~g}$ (81\%), m.p. 93.5-96 ${ }^{\circ} \mathrm{C} .{ }^{1} \mathrm{H}-\mathrm{NMR}\left(\mathrm{CDCl}_{3}, 500 \mathrm{MHz}\right): \delta 9.01$ (br $\mathrm{s}, 1 \mathrm{H}), 7.38-7.39(\mathrm{~m}, 3 \mathrm{H}), 7.32-7.34(\mathrm{~m}, 2 \mathrm{H}), 5.09$ (br s, 2H), $4.48(\mathrm{~s}, 1 \mathrm{H}), 2.71$ (d, J = 5.2 Hz, $3 \mathrm{H}) ;{ }^{13} \mathrm{C}-\mathrm{NMR}\left(\mathrm{CDCl}_{3}, 125 \mathrm{MHz}\right): \delta 172.7,164.2,136.3,129.0,128.3,127.9,86.1,31.3$. For elemental analysis, the product was recrystallized from the cyclohexane/toluene mixture. Anal. Calc. for $\mathrm{C}_{10} \mathrm{H}_{12} \mathrm{~N}_{2} \mathrm{O}$ : C, 68.16; H, 6.86; N, 15.90. Found: C, 68.40; H, 6.90; N, 15.87\%.

3-Amino-N-methylbut-2-enamide (1e). The title compound was prepared according to a modified published procedure [43]. Dry ammonia gas was bubbled into a mixture of 
$N$-methyl-3-oxobutanamide (4c) $(2.26 \mathrm{~g}, 19.6 \mathrm{mmol})$, dry toluene $(10 \mathrm{~mL})$, and molecular sieve $(1 \mathrm{~g})$ over a period of $2 \mathrm{~h}$ at $10^{\circ} \mathrm{C}$. Then ethanol $(30 \mathrm{~mL})$ was added. The solid was dissolved, the mixture was filtered off, and the filtrate was evaporated to dryness. Cold diethyl ether was added, and the mixture was stirred. Then the white crystals were filtered off. This compound must be stored in the refrigerator. Yield $1.59 \mathrm{~g}(71 \%), \mathrm{m} . \mathrm{p} .95 .5-99{ }^{\circ} \mathrm{C}$ (Ref. [43] 115-116 ${ }^{\circ} \mathrm{C}$ ). ${ }^{1} \mathrm{H}-\mathrm{NMR}\left(\mathrm{CDCl}_{3}, 400 \mathrm{MHz}\right): \delta 6.33$ (br s, 2H), 5.26 (br s, 1H), 4.36 (s, $1 \mathrm{H}), 2.78(\mathrm{~d}, J=4.9 \mathrm{~Hz}, 3 \mathrm{H}), 1.84(\mathrm{~s}, 3 \mathrm{H}) ;{ }^{13} \mathrm{C} \mathrm{NMR}\left(\mathrm{CDCl}_{3}, 100 \mathrm{MHz}\right): \delta 171.3,156.0,86.6$, 25.6, 22.3. Anal. Calc. for $\mathrm{C}_{5} \mathrm{H}_{10} \mathrm{~N}_{2} \mathrm{O}$ : C, 52.61; $\mathrm{H}, 8.81 ; \mathrm{N}, 24.54$. Found: $\mathrm{C}, 52.58 ; \mathrm{H}, 8.93$; $\mathrm{N}, 23.81 \%$.

3-Amino-N-methyl-3-phenylprop-2-enamide (1f). The title compound was prepared according to the published procedure [44]. N-Methyl-3-oxo-3-phenylpropanamide (4d) (7 g, $40 \mathrm{mmol})$, ammonium acetate $(16.3 \mathrm{~g}, 200 \mathrm{mmol})$ and methanol $(100 \mathrm{~mL})$ were stirred at $55{ }^{\circ} \mathrm{C}$ for 3 days. Then, aqueous ammonia $(50 \mathrm{~mL})$ was added. The reaction mixture was extracted with dichloromethane $(2 \times 50 \mathrm{~mL})$. The organic layer was dried with anhydrous sodium sulphate, and solvent was removed by distillation. Dichloromethane $(50 \mathrm{~mL})$ was added to the residue, and the organic layer was again extracted with water $(1 \times 50 \mathrm{~mL})$. The organic layer was dried with anhydrous sodium sulphate, and solvent was removed by distillation. Recrystallization from ethyl acetate was obtained $3.78 \mathrm{~g} \mathrm{(55 \% ).} \mathrm{White} \mathrm{crystals,}$ m.p. $127-130{ }^{\circ} \mathrm{C} .{ }^{1} \mathrm{H}-\mathrm{NMR}\left(\mathrm{CDCl}_{3}, 400 \mathrm{MHz}\right): \delta 7.28-7.40(\mathrm{~m}, 5 \mathrm{H}), 6.56(\mathrm{~s}, 2 \mathrm{H}), 5.47(\mathrm{~s}, 1 \mathrm{H})$, $4.8(\mathrm{~s}, 1 \mathrm{H}), 2.83(\mathrm{~d}, J=5.2 \mathrm{~Hz}, 3 \mathrm{H}) ;{ }^{13} \mathrm{C}-\mathrm{NMR}\left(\mathrm{CDCl}_{3}, 100 \mathrm{MHz}\right): \delta 171.1,157.3,138.5,129.7$, 128.7, 126.1, 87.5, 25.9. Anal. Calc. for $\mathrm{C}_{10} \mathrm{H}_{12} \mathrm{~N}_{2} \mathrm{O}$ : $\mathrm{C}, 68.16 ; \mathrm{H}, 6.86 ; \mathrm{N}, 15.90$. Found: $\mathrm{C}$, $68.24 ; \mathrm{H}, 6.98 ; \mathrm{N}, 15.71 \%$.

N-Methyl-3-(methylamino)but-2-enamide (1g). N-Methyl-3-oxobutanamide (4c) (2.65 g, $23 \mathrm{mmol}): 33 \mathrm{wt} \%$ solution of methylamine in ethanol $(8.6 \mathrm{~mL}, 69 \mathrm{mmol})$ and montmorillonite K-10 (5.8 g) was boiled ca $60 \mathrm{~min}$. After cooling, dichloromethane $(10 \mathrm{~mL})$ was added, and montmorillonite was filtered and washed with dichloromethane $(4 \times 20 \mathrm{~mL})$. Dichloromethane was distilled off, and the residue solidified in the refrigerator overnight. Then the beige crystals were filtered off. This compound must be stored in the refrigerator. Yield $2.63 \mathrm{~g}(89 \%)$, m.p. $50-54{ }^{\circ} \mathrm{C} .{ }^{1} \mathrm{H}-\mathrm{NMR}\left(\mathrm{CDCl}_{3}, 400 \mathrm{MHz}\right): \delta 5.87$ (br s, $\left.1 \mathrm{H}\right), 5.23$ (br $\mathrm{s}, 1 \mathrm{H}), 4.33(\mathrm{~s}, 1 \mathrm{H}), 2.85(\mathrm{~d}, J=5.2 \mathrm{~Hz}, 3 \mathrm{H}), 2.75(\mathrm{~d}, J=4.9 \mathrm{~Hz}, 3 \mathrm{H}), 1.86(\mathrm{~s}, 3 \mathrm{H})$; ${ }^{13} \mathrm{C}-\mathrm{NMR}$ $\left(\mathrm{CDCl}_{3}, 100 \mathrm{MHz}\right): \delta 171.7$ (br), 158.9 (br), 84.3 (br), 29.2, 25.5 (br), 19.0. HR-MS (MALDI), cald. for $\mathrm{C}_{6} \mathrm{H}_{13} \mathrm{~N}_{2} \mathrm{O}:[\mathrm{M}+\mathrm{H}]^{+} 129.1022$, found: $129.1023[\mathrm{M}+\mathrm{H}]^{+}$.

N-Methyl-3-(methylamino)-3-phenylprop-2-enamide (1h). The method according to Štefane and Polanc was used [33]. The solution of $3 \mathbf{b}(3.38 \mathrm{~g}, 15 \mathrm{mmol})$ and $33 \mathrm{wt} \%$ methylamine in ethanol $(9.3 \mathrm{~mL})$ in propan-1-ol $(65 \mathrm{~mL})$ was heated with stirring in an Ace pressure tube at $130-140{ }^{\circ} \mathrm{C}$. After heating for $4 \mathrm{~h}$, the reaction mixture was evaporated under reduced pressure, and the residue was cooled. Slightly yellowish crystals were filtered off. Yield $4 \mathrm{~g}(96 \%)$, m.p. $101-105{ }^{\circ} \mathrm{C} .{ }^{1} \mathrm{H}-\mathrm{NMR}\left(\mathrm{CDCl}_{3}, 400 \mathrm{MHz}\right): \delta 8.86$ (br s, 1H), 7.34-7.36 (m, 3H), 7.29-7.32 (m, 2H), 5.39 (br s, 1H), 4.45 (s, 1H), 2.79 (d, J = 4.9 Hz, $3 \mathrm{H}), 2.64(\mathrm{~d}, J=5.3 \mathrm{~Hz}, 3 \mathrm{H}) ;{ }^{13} \mathrm{C}-\mathrm{NMR}\left(\mathrm{CDCl}_{3}, 100 \mathrm{MHz}\right): \delta 171.3,162.4,136.6,128.7,128.2$, $127.9,87.9,31.2,25.7$. For elemental analysis, this compound was recrystallized from the cyclohexane/toluene mixture. Anal. Calc. for $\mathrm{C}_{11} \mathrm{H}_{14} \mathrm{~N}_{2} \mathrm{O}: \mathrm{C}, 69.45 ; \mathrm{H}, 7.42 ; \mathrm{N}, 14.73$. Found: C, 69.58; H, 7.50; N, 14.70\%.

General procedure for the preparation of 4-ethoxy-2,2-difluoro-1,3,2-dioxoborinanes $\mathbf{2 a}$, $\mathbf{b}$. A modified method according to Štefane and Polanc was used [33]. To a solution of ethyl benzoylacetate (156 mmol, $30 \mathrm{~g}$ ) in dichloromethane (35 mL) 48\% BF $3-\mathrm{Et}_{2} \mathrm{O}(312 \mathrm{mmol}$, $39.6 \mathrm{~mL}$ ) was added at $23-25^{\circ} \mathrm{C}$. After stirring at $23-25^{\circ} \mathrm{C}$ for $24 \mathrm{~h}$, the precipitated material was filtered off. All volatile materials were removed under vacuum from the filtrate. Cooled diethyl ether $(100 \mathrm{~mL})$ was added to the residue, and after stirring for $5 \mathrm{~min}$, the crystals were filtered off. Filtrate was evaporated again, and the residue was stirred with a small amount of cooled diethyl ether. The precipitated crystals were filtered off. The total yield of white crystals was $26.95 \mathrm{~g}$ (72\%). M.p. 105-106 ${ }^{\circ} \mathrm{C}$ (Ref. [45] 108-110 ${ }^{\circ} \mathrm{C}$ ). For compound 2a: After stirring at $23-25^{\circ} \mathrm{C}$ for $26.5 \mathrm{~h}$, all volatile materials were removed under vacuum, and the yellow oily product was used for the preparation of compound 3a without purification. 
2,2-Difluoro-4-methyl-6-(methylamino)-1,3,2-dioxoborinane (3a). The method according to Štefane and Polanc was used [33]. To a stirred solution of $33 \mathrm{wt} \%$ methylamine in ethanol (37 mL, $297 \mathrm{mmol}$ ) and acetonitrile $(245 \mathrm{~mL})$, crude dioxoborinane $\mathbf{2} \mathbf{a}$ was added at $23^{\circ} \mathrm{C}$. The reaction mixture was stirred $30 \mathrm{~min}$ at $23{ }^{\circ} \mathrm{C}$. The solvents were evaporated, and the residue was separated by column chromatography using dichloromethane as an eluent to give $16.85 \mathrm{~g}$ (45\%). Light-yellow crystals, m.p. $95-99{ }^{\circ} \mathrm{C} .{ }^{1} \mathrm{H}-\mathrm{NMR}\left(\mathrm{CDCl}_{3}, 400 \mathrm{MHz}\right): \delta$ 7.30 (br s, 1H, maj.), 6.51 (br s, 0,09H, min.), 5.36 (s, 1H, min.), 5.33 (s, 1H, maj.), 3.00 (d, $J=4,8 \mathrm{~Hz}, 3.26 \mathrm{H}$, maj. + min.), 2.16 (s, 0,30H, min.), 2.05 (s, 3H, maj.); ${ }^{13} \mathrm{C}-\mathrm{NMR}\left(\mathrm{CDCl}_{3}\right.$, $100 \mathrm{MHz}$ ): $\delta 181.1$ (min.), 176.8 (maj.), 169.2 (min.), 168.8 (maj.), 87.8 (maj.), 84.0 (min.), 28.7 (min.), 27.2 (maj.), 23.3 (min.), 22.5 (maj.); ${ }^{19} \mathrm{~F} \mathrm{NMR}\left(\mathrm{CDCl}_{3}, 376 \mathrm{MHz}\right): \delta-142.20\left({ }^{19} \mathrm{~F}-{ }^{11} \mathrm{~B}\right.$, 0.8F, min. $),-142.14\left({ }^{19} \mathrm{~F}-{ }^{10} \mathrm{~B}, 0.2 \mathrm{~F}, \mathrm{~min}.\right),-142.09\left({ }^{19} \mathrm{~F}-{ }^{11} \mathrm{~B}, 0.8 \mathrm{~F}\right.$, maj. $),-142.03\left({ }^{19} \mathrm{~F}-{ }^{10} \mathrm{~B}, 0.2 \mathrm{~F}\right.$, maj.). For elemental analysis, this compound was recrystallized from ethyl acetate. Anal. Calc. for $\mathrm{C}_{5} \mathrm{H}_{8} \mathrm{BF}_{2} \mathrm{NO}_{2}$ : C, 36.86; H, 4.95; N, 8.60. Found: C 37.12; $\mathrm{H} 5.07 ; \mathrm{N} \mathrm{8.63 \% .}$

2,2-Difluoro-6-(methylamino)-4-phenyl-1,3,2-dioxoborinane (3b). The method according to Štefane and Polanc was used [33]. To a stirred solution of $33 \mathrm{wt} \%$ methylamine in ethanol $(18.1 \mathrm{~mL}, 146 \mathrm{mmol})$ and acetonitrile $(118 \mathrm{~mL})$, dioxoborinane $2 \mathbf{b}(26.95 \mathrm{~g}, 112 \mathrm{mmol})$ was added at room temperature. The reaction mixture was stirred for $30 \mathrm{~min}$ at room temperature. The solvents were evaporated, and the residue was stirred in diethyl ether $(40 \mathrm{~mL})$. The crystals were filtered off. White crystals, yield $25 \mathrm{~g}(84 \%), \mathrm{m} . \mathrm{p} .164-168{ }^{\circ} \mathrm{C}$. ${ }^{1} \mathrm{H}-\mathrm{NMR}$ (DMSO-d $\left.6,500 \mathrm{MHz}\right): \delta 8.07-8.08$ (m, 0.21H, min.), 7.87-7.88 (m, 2H, maj.), 7.54-7.62 (m, 3.37H, maj. + min.), 6,42 (s, 0.1H, min.), 6.14 (s, 1H, maj.), 3.05 (s, 0.36H, min.), 2.96 (s, 3H, maj.); ${ }^{13}$ C-NMR (DMSO-d $6,125 \mathrm{MHz}$ ): $\delta 171.9$ (min.), 169.0 (maj.), 168.9 (min.), 168.2 (maj.), 133.0 (min.), 132.9 (maj.), 132.6 (min.), 132.2 (maj.), 129.0 (maj.), 128.9 (min.), 126.6 (min.), 126.5 (maj.), 85.6 (maj.), 81.2 (min.), 28.5 (min.), 26.9 (maj.); ${ }^{19}$ F-NMR (DMSO- $\left.d_{6}, 470 \mathrm{MHz}\right): \delta-141.77\left({ }^{19} \mathrm{~F}-{ }^{11} \mathrm{~B}, 0.8 \mathrm{~F}, \mathrm{~min}.\right),-141.71\left({ }^{19} \mathrm{~F}-{ }^{10} \mathrm{~B}, 0.2 \mathrm{~F}, \mathrm{~min}.\right),-141.49$ $\left({ }^{19} \mathrm{~F}-{ }^{11} \mathrm{~B}, 0.8 \mathrm{~F}\right.$, maj. $),-141.44\left({ }^{19} \mathrm{~F}-{ }^{10} \mathrm{~B}, 0.2 \mathrm{~F}\right.$, maj. $)$. For elemental analysis, this compound was recrystallized from ethanol. Anal. Calc. for $\mathrm{C}_{10} \mathrm{H}_{10} \mathrm{BF}_{2} \mathrm{NO}_{2}$ : C, 53.38; $\mathrm{H}, 4.48 ; \mathrm{N}, 6.23$. Found: C 53.68; H 4.60; N 6.23\%.

3-Oxo-3-phenylprop-2-enamide (4b). This compound was prepared according to the procedure in Ref. [32]. 3-Amino-3-phenylprop-2-enamide (1b) (8 g, 49 mmol) was heated in water $(33 \mathrm{~mL})$ for $4 \mathrm{~h}$. After cooling, the solid product was filtered off. Crystals were crystallized from water. Yellowish crystals, yield $4.62 \mathrm{~g}(57 \%)$, m.p. 108-111 ${ }^{\circ} \mathrm{C}$ (Ref. [32] $\left.110-111^{\circ} \mathrm{C}\right)$.

N-Methyl-3-oxobutanamide (4c). This compound was prepared according to the procedure in Ref. [33]. The mixture of 2,2-difluoro-4-methyl-6-(methylamino)-1,3,2-dioxoborinane (3a) $(9 \mathrm{~g}, 55 \mathrm{mmol})$, sodium acetate $(22,7 \mathrm{~g}, 276 \mathrm{mmol})$, and ethanol/water $(36 \mathrm{~mL} / 36 \mathrm{~mL})$ was refluxed with stirring for $6 \mathrm{~h}$. The solvents were evaporated, and the residue was washed several times with $\mathrm{CH}_{2} \mathrm{Cl}_{2}(25 \mathrm{~mL})$. Dichloromethane was evaporated, and the residue was purified by vacuum distillation. Light yellow liquid, yield $4.56 \mathrm{~g}$ (72\%), b.p. 95-99 ${ }^{\circ} \mathrm{C} / 2-3$ mbar (Ref. [46] 96-98 ${ }^{\circ} \mathrm{C} / 0.13$ mbar).

N-Methyl-3-oxo-3-phenylpropanamide (4d). This compound was prepared according to the procedure in Ref. [33]. The mixture of 2,2-difluoro-4-(methylamino)-6-phenyl-1,3,2dioxoborinane (3b) (11.4 g, $50 \mathrm{mmol})$, sodium acetate $(20.5 \mathrm{~g}, 250 \mathrm{mmol})$, and ethanol/water $(50 \mathrm{~mL} / 50 \mathrm{~mL})$ was refluxed with stirring for $13 \mathrm{~h}$. The reaction mixture was extracted with dichloromethane $(2 \times 100 \mathrm{~mL})$. The organic layer was dried with anhydrous sodium sulphate, and the solvent was removed by distillation. White crystals, yield $7.52 \mathrm{~g}(85 \%)$, m.p. 101.5-103.5 ${ }^{\circ} \mathrm{C}$ (Ref. [47] 101-102 ${ }^{\circ} \mathrm{C}$ ).

4-Methylbenzenediazonium tetraphenylborate. 4-Methylaniline $(0.73 \mathrm{~g}, 6.84 \mathrm{mmol})$ was dissolved in boiling aqueous hydrochloric acid $(3 \mathrm{~mL}, 1: 1)$. The solution was cooled to $-5{ }^{\circ} \mathrm{C}$ and diazotized by gradual addition of a cold solution of sodium nitrite $(0.49 \mathrm{~g}, 7.11 \mathrm{mmol})$ in water $(1.5 \mathrm{~mL})$. The temperature during diazotization was maintained between -5 and $0{ }^{\circ} \mathrm{C}$. The excess of nitrous acid (presence tested by starch iodide paper) was decomposed using the required amount of sulfamic acid. A solution of sodium tetraphenylborate $(2.34 \mathrm{~g}, 6.84 \mathrm{mmol})$ in water $(75 \mathrm{~mL})$ was added at once. The precipitated diazonium salt 
was filtered and washed with cold ethanol $(1 \times 30 \mathrm{~mL})$ and diethyl ether $(2 \times 30 \mathrm{~mL})$. The diazonium salt was prepared immediately prior to use and dried in vacuo at room temperature in a desiccator for about $1 \mathrm{~h}$ (CAUTION: Dry diazonium tetraphenylborates can undergo violent decomposition when the crystalline material is ground!). The yield of diazonium salt was $2.81 \mathrm{~g}(94 \%)$, yellow powder.

General Procedure for the Reaction of $\mathbf{1 a}-\mathbf{h}$ with 4-Methylbenzenediazonium Tetraphenylborate

Method A. A stoichiometric amount of freshly prepared 4-methylbenzenediazonium tetraphenylborate $(2.19 \mathrm{~g}, 5 \mathrm{mmol})$ was added to a stirred solution of $\beta$-enaminoamide $\mathbf{1 a}-\mathbf{h}(5 \mathrm{mmol})$ in dry dichloromethane $(35 \mathrm{~mL})$ at $10{ }^{\circ} \mathrm{C}$. The reaction mixture was stirred at room temperature for 3-6 days. Then it was filtered, and the solvent was removed in vacuo. The crude residue was separated by column chromatography.

Method B. The procedure was the same as for Method A, except remelted sodium acetate $(1.23 \mathrm{~g}, 15 \mathrm{mmol})$ was finely ground and added to a stirred solution of $\beta$-enaminoamide $\mathbf{1 a}-\mathbf{h}$ and 4-methylbenzenediazonium tetraphenylborate. The reaction mixture was stirred at room temperature for 3-6 days. Then it was filtered, and the solvent was removed in vacuo. The crude residue was separated by column chromatography.

Method $\mathrm{C}$. To a cold $\left(5^{\circ} \mathrm{C}\right)$ solution of $\beta$-enaminoamides $\mathbf{1 a}-\mathbf{h}(5 \mathrm{mmol})$ in dry dichloromethane $(15 \mathrm{~mL})$ and dry toluene $(25 \mathrm{~mL})$ was added freshly prepared 4-methylbenzenediazonium tetraphenylborate $(2.19 \mathrm{~g}, 5 \mathrm{mmol})$. The reaction mixture was stirred $30 \mathrm{~min}$ at room temperature and then refluxed for $3-5 \mathrm{~h}$. The reaction mixture was cooled to room temperature and the solvents evaporated. The crude residue was separated by column chromatography.

6-(1-Aminoethylidene)-2-(4-methylphenyl)-3,3-diphenyl-4H-1,2,4,3 $\lambda^{4}$-triazaborine-5-one (5a). After column chromatography (silica gel $\left./ \mathrm{CH}_{2} \mathrm{Cl}_{2}\right)$ and boiling in ethanol $(5 \mathrm{~mL})$, the title compound was obtained as yellow crystals. Yield $1.16 \mathrm{~g}(61 \%$, Method A, $72 \mathrm{~h}), 1.10 \mathrm{~g}$ (58\%, Method B, $72 \mathrm{~h}$ ) and $1.16 \mathrm{~g}(61 \%$, Method C, reflux $2.5 \mathrm{~h})$, m.p. $237-240{ }^{\circ} \mathrm{C} .{ }^{1} \mathrm{H}-\mathrm{NMR}$ (DMSO- $\left.d_{6}, 400 \mathrm{MHz}\right): \delta 12.12(\mathrm{~s}, 1 \mathrm{H}), 10.63(\mathrm{~s}, 1 \mathrm{H}), 7.32-7.34(\mathrm{~m}, 4 \mathrm{H}), 7.23-7.25(\mathrm{~m}, 2 \mathrm{H})$, 7.17-7.20 (m, 4H), 7.09-7.12 (m, 2H), 6.94-6.96 (m, 2H), $6.80(\mathrm{~s}, 1 \mathrm{H}), 2.54(\mathrm{~s}, 3 \mathrm{H}), 2.20(\mathrm{~s}, 3 \mathrm{H})$; ${ }^{13}$ C-NMR (DMSO- $d_{6}, 100$ MHz): $\delta 176.1,160.7,150.7$ (br s), 146.0, 135.4, 133.4, 128.4, 127.0, $125.4,123.3,122.2,20.5,18.5$. For elemental analysis, compound 5a was recrystallized from toluene. Anal. Calc. for $\mathrm{C}_{23} \mathrm{H}_{23} \mathrm{BN}_{4} \mathrm{O}$ : C, 72.27; $\mathrm{H}, 6.06$; N, 14.66. Found: $\mathrm{C}, 71.99 ; \mathrm{H}, 6.13$; $\mathrm{N}, 14.39 \%$.

6-Amino-4-methyl-5-[4-(methylphenyl)diazenyl)]-2,2-diphenyl-3H-1,3,2 $\lambda^{4}$-oxazaborine (6a). After column chromatography (silica gel $/ \mathrm{CH}_{2} \mathrm{Cl}_{2}$ ) and recrystallization from the ethanol/ ethyl acetate mixture, compound 6a was obtained as yellow crystals. Yield $0.08 \mathrm{~g}(4 \%$, Method A, 72 h), $0.14 \mathrm{~g}$ (7\%, Method B, 72 h), m.p. $215-218{ }^{\circ} \mathrm{C} .{ }^{1} \mathrm{H}-\mathrm{NMR}\left(\mathrm{CDCl}_{3}, 500 \mathrm{MHz}\right)$ : $\delta 11.32(\mathrm{~s}, 1 \mathrm{H}), 7.40-7.44(\mathrm{~m}, 6 \mathrm{H}), 7.28-7.31(\mathrm{~m}, 4 \mathrm{H}), 7.22-7.25(\mathrm{~m}, 2 \mathrm{H}), 7.16-7.20(\mathrm{~m}, 2 \mathrm{H})$, $6.84(\mathrm{~s}, 1 \mathrm{H}), 6.15$ (br d, J = 3 Hz, 1H), 2.54 (s, 3H), 2.36 (s, 3H); ${ }^{13} \mathrm{C}-\mathrm{NMR}\left(\mathrm{CDCl}_{3}, 125 \mathrm{MHz}\right)$ : $\delta 170.3,162.1,150.4,149.1$ (br s), 137.8, 132.0, 129.7, 127.6, 126.7, 120.7, 114.6, 21.5, 21.3. Anal. Calc. for $\mathrm{C}_{23} \mathrm{H}_{23} \mathrm{BN}_{4} \mathrm{O}$ : C, 72.27; $\mathrm{H}, 6.06 ; \mathrm{N}, 14.66$. Found: $\mathrm{C}, 72.10 ; \mathrm{H}, 6.21 ; \mathrm{N}, 14.72 \%$.

6-(Amino(phenyl)methylidene)-2-(4-methylphenyl)-3,3-diphenyl-4H-1,2,4,3 $\lambda^{4}$-triazaborine-5one (5b). After column chromatography (silica gel $/ \mathrm{CH}_{2} \mathrm{Cl}_{2}$ ) and recrystallization from the ethanol/toluene mixture, the title compound was obtained as yellow crystals. Yield $1.11 \mathrm{~g}$ (50\%, Method A, 72 h), $0.82 \mathrm{~g} \mathrm{(37 \% ,} \mathrm{Method} \mathrm{B,} 72 \mathrm{~h})$ and $1.22 \mathrm{~g}$ (55\%, Method C, reflux 2.5 h), m.p. $133-137{ }^{\circ} \mathrm{C} .{ }^{1} \mathrm{H}-\mathrm{NMR}\left(\mathrm{CDCl}_{3}, 500 \mathrm{MHz}\right.$ ): $\delta 12.00$ (br s, $\left.1 \mathrm{H}\right), 8.26$ (br s, $\left.1 \mathrm{H}\right)$, 7.42-7.44 (m, 2H), 7.32-7.36 (m, 5H), 7.21-7.27 (m, 6H), 7.20-7.18 (m, 2H), 6.99-7.01 (m, 2H), 6.74-6.76 (m, 2H), 5.18 (br s, 1H), 2.13 (s, 3H); ${ }^{13} \mathrm{C}-\mathrm{NMR}\left(\mathrm{CDCl}_{3}, 125 \mathrm{MHz}\right): \delta 173.3,161.9$, 149.4 (br s), 145.7, 137.0, 133.6, 133.4, 132.1, 129.8, 128.6, 128.3, 127.4, 126.1, 122.8, 122.7, 21.0. Anal. Calc. for $\mathrm{C}_{28} \mathrm{H}_{25} \mathrm{BN}_{4} \mathrm{O}$ : C, 75.69, H, 5.67, N, 12.61. Found: C, 75.78, H, 5.86, N, 12.60\%.

5-[(4-Methylphenyl)hydrazono]-2,2,6-triphenyl-1H,3H-1,3,2 $\lambda^{4}$-diazaborine-4-one (7b). After column chromatography (silica gel $/ \mathrm{CH}_{2} \mathrm{Cl}_{2}$ ) and boiling in cyclohexane $(4 \mathrm{~mL})$, the title compound was obtained as yellow crystals. Yield $0.22 \mathrm{~g} \mathrm{(10 \% ,} \mathrm{Method} \mathrm{A,} 72 \mathrm{~h}), 0.46 \mathrm{~g}(21 \%$, 
Method B, 72 h), m.p. $255-260{ }^{\circ} \mathrm{C} .{ }^{1} \mathrm{H}-\mathrm{NMR}\left(\mathrm{CDCl}_{3}, 500 \mathrm{MHz}\right): \delta 15.35$ (br s, $\left.1 \mathrm{H}\right), 8.46$ (br s, $1 \mathrm{H}), 7.53-7.57(\mathrm{~m}, 3 \mathrm{H}), 7.45-7.48(\mathrm{~m}, 2 \mathrm{H}), 7.39-7.41(\mathrm{~m}, 4 \mathrm{H}), 7.28-7.31(\mathrm{~m}, 4 \mathrm{H}), 7.21-7.23(\mathrm{~m}$ 2H), 7.07-7.09 (m, 2H), 6.96-6.97 (m, 2H), 5.73 (br s, $1 \mathrm{H}), 2.29(\mathrm{~s}, 3 \mathrm{H}) ;{ }^{13} \mathrm{C}-\mathrm{NMR}\left(\mathrm{CDCl}_{3}\right.$, $125 \mathrm{MHz}$ ): $\delta$ 170.5, 164.7, 150.0 (br), 139.3, 135.7, 134.2, 132.4, 132.0, 130.2, 129.4, 128.5, 127.8, 126.5, 122.1, 116.1, 21.1. Anal. Calc. for $\mathrm{C}_{28} \mathrm{H}_{25} \mathrm{BN}_{4} \mathrm{O}: \mathrm{C}, 75.69, \mathrm{H}, 5.67, \mathrm{~N}, 12.61$. Found: $\mathrm{C}$, $75.89, \mathrm{H}, 5.78, \mathrm{~N}, 14.46 \%$.

6-[1-(Methylamino)ethylidene]-2-(4-methylphenyl)-3,3-diphenyl-4H-1,2,4,3 $\lambda^{4}$-triazaborine-5one (5c). After column chromatography (silica gel/ $\mathrm{CH}_{2} \mathrm{Cl}_{2}$ ) and recrystallization from toluene, the title compound was obtained as yellow crystals. Yield $0.85 \mathrm{~g} \mathrm{(43 \% ,} \mathrm{Method} \mathrm{A,}$ $72 \mathrm{~h}), 0.95 \mathrm{~g}(48 \%$, Method B, $72 \mathrm{~h})$ and $1.38 \mathrm{~g}\left(69 \%\right.$, Method C, reflux 2.5 h), m.p. 224-227 ${ }^{\circ} \mathrm{C}$. ${ }^{1} \mathrm{H}-\mathrm{NMR}\left(\mathrm{CDCl}_{3}, 400 \mathrm{MHz}\right): \delta 13.40(\mathrm{~s}, 1 \mathrm{H}), 7.38-7.40(\mathrm{~m}, 4 \mathrm{H}), 7.19-7.23(\mathrm{~m}, 6 \mathrm{H}), 7.12-7.17$ $(\mathrm{m}, 2 \mathrm{H}), 6.89-6.91(\mathrm{~m}, 2 \mathrm{H}), 5,51(\mathrm{~s}, 1 \mathrm{H}), 3.17(\mathrm{~d}, \mathrm{~J}=5.3 \mathrm{~Hz}, 3 \mathrm{H}), 2.50(\mathrm{~s}, 3 \mathrm{H}), 2.21(\mathrm{~s}, 3 \mathrm{H})$; ${ }^{13} \mathrm{C}-\mathrm{NMR}\left(\mathrm{CDCl}_{3}, 100 \mathrm{MHz}\right): \delta 174.9,162.2,149.8$ (br s), 146.2, 136.4, 133.7, 128.6, 127.2, 126.0, 123.4, 122.8, 31.7, 21.0, 13.8. Anal. Calc. for $\mathrm{C}_{24} \mathrm{H}_{25} \mathrm{BN}_{4} \mathrm{O}: \mathrm{C}, 72.74, \mathrm{H}, 6.36, \mathrm{~N}, 14.14$. Found: C, 73.01, H, 6.45, N, 13.95\%.

1,6-Dimethyl-5-[(4-methylphenyl)hydrazono]-2,2-diphenyl-3H-1,3,2 $\lambda^{4}$-diazaborine-4-one (7c). After column chromatography (silica gel $/ \mathrm{CH}_{2} \mathrm{Cl}_{2}$ ) and boiling in ethanol $(3 \mathrm{~mL})$, the title compound was obtained as yellow crystals. Yield $0.15 \mathrm{~g}(8 \%$, Method B, $72 \mathrm{~h})$, m.p. 213-216 ${ }^{\circ} \mathrm{C} .{ }^{1} \mathrm{H}-\mathrm{NMR}\left(\mathrm{CDCl}_{3}, 400 \mathrm{MHz}\right): \delta 15.24(\mathrm{~s}, 1 \mathrm{H}), 7.39-7.42(\mathrm{~m}, 4 \mathrm{H}), 7.27-7.31$ (m, $4 \mathrm{H}), 7.21-7.25(\mathrm{~m}, 4 \mathrm{H}), 7.14-7.16(\mathrm{~m}, 2 \mathrm{H}), 5.61(\mathrm{~s}, 1 \mathrm{H}), 3.10(\mathrm{~s}, 3 \mathrm{H}), 2.54(\mathrm{~s}, 3 \mathrm{H}), 2.32(\mathrm{~s}, 3 \mathrm{H})$; ${ }^{13} \mathrm{C}-\mathrm{NMR}\left(\mathrm{CDCl}_{3}, 125 \mathrm{MHz}\right): \delta 171.7,163.2,148.5$ (br s), 139.7, 134.9, 133.3, 130.2, 127.7, 126.5, 123.8, 115.7, 39.7, 21.1, 15.5. Anal. Calc. for $\mathrm{C}_{24} \mathrm{H}_{25} \mathrm{BN}_{4} \mathrm{O}: \mathrm{C}, 72.74, \mathrm{H}, 6.36, \mathrm{~N}, 14.14$. Found: C, 73.04, H, 6.62, N, 13.85\%.

6-[(Methylamino)(phenyl)methyliden]-2-(4-methylphenyl)-3,3-diphenyl-4H-1,2,4,3 $\lambda^{4}$-triazaborine-5one (5d). After column chromatography (silica gel $/ \mathrm{CH}_{2} \mathrm{Cl}_{2} /$ EtOAc (10:1)) and boiling in ethanol, the title compound was obtained as yellow crystals. Yield $1.5 \mathrm{~g}(65.5 \%$, Method A, $104 \mathrm{~h}), 1.8 \mathrm{~g}$ (79\%, Method B, $72 \mathrm{~h})$, and $1.57 \mathrm{~g} \mathrm{(68.5 \% ,} \mathrm{Method} \mathrm{C,} \mathrm{reflux} \mathrm{5h),} \mathrm{m.p.} 184-187{ }^{\circ} \mathrm{C}$. ${ }^{1} \mathrm{H}-\mathrm{NMR}\left(\mathrm{CDCl}_{3}, 500 \mathrm{MHz}\right): \delta 13.22(\mathrm{br} \mathrm{q}, J=5 \mathrm{~Hz}, 1 \mathrm{H}), 7.39-7.45(\mathrm{~m}, 7 \mathrm{H}), 7.25-7.26(\mathrm{~m}$, 2H), 7.18-7.21 (m, 4H), 7.11-7.13 (m, 2H), 6.89-6.92 (m, 2H), 6.65-6.67 (m, 2H), $5.7(\mathrm{~s}, 1 \mathrm{H})$, $2.88(\mathrm{~d}, J=5 \mathrm{~Hz}, 3 \mathrm{H}), 2.05(\mathrm{~s}, 3 \mathrm{H}) ;{ }^{13} \mathrm{C}-\mathrm{NMR}\left(\mathrm{CDCl}_{3}, 125 \mathrm{MHz}\right): \delta$ 174.3, 162.0, 149.6 (br s), 145.7, 136.1, 133.5, 130.4, 130.0, 128.5, 128.3, 128.2, 127.2, 125.8, 123.6, 122.2, 33.1, 20.7. For elemental analysis, compound $\mathbf{5 d}$ was recrystallized from the cyclohexane/toluene mixture. Anal. Calc. for $\mathrm{C}_{24} \mathrm{H}_{25} \mathrm{BN}_{4} \mathrm{O}$ : C, 72.74, H, 6.36, N, 14.14. Found: C, 73.01, H, 6.45, $\mathrm{N}, 13.95 \%$

1-Methyl-5-[(4-methylphenyl)hydrazono]-2,2,6-triphenyl-3H-1,3,2 $\lambda^{4}$-diazaborine-4-one (7d). After column chromatography (silica gel/ $\mathrm{CH}_{2} \mathrm{Cl}_{2} /$ EtOAc (10:1)) and boiling in ethanol for $5 \mathrm{~min}$, the title compound was obtained as yellow crystals. Yield $0.04 \mathrm{~g}(1.7 \%$, Method A, $104 \mathrm{~h}), 0.24 \mathrm{~g}$ (10.5\%, Method B, $72 \mathrm{~h})$, and $0.22 \mathrm{~g}(9.6 \%$, Method C, reflux 5 h), m.p. 207.5-211 ${ }^{\circ} \mathrm{C} .{ }^{1} \mathrm{H}-\mathrm{NMR}\left(\mathrm{CDCl}_{3}, 500 \mathrm{MHz}\right): \delta 15.07(\mathrm{~s}, 1 \mathrm{H}), 7.49-7.51(\mathrm{~m}, 7 \mathrm{H}), 7.32-7.35(\mathrm{~m}$, $4 \mathrm{H}), 7.26-7.27(\mathrm{~m}, 4 \mathrm{H}), 6.98-7.00(\mathrm{~m}, 2 \mathrm{H}), 6.75-6.76(\mathrm{~m}, 2 \mathrm{H}), 5.68(\mathrm{~s}, 1 \mathrm{H}), 2.89(\mathrm{~s}, 3 \mathrm{H}), 2.24(\mathrm{~s}$, $3 \mathrm{H}) ;{ }^{13} \mathrm{C}-\mathrm{NMR}\left(\mathrm{CDCl}_{3}, 125 \mathrm{MHz}\right): \delta 172.6,163.7,148.6$ (br s), 139.5, 134.9, 133.3, 133.1, 130.0, $129.6,128.5,127.7,127.5,126.6,124.8,115.6,41.1,21.0$. For elemental analysis, compound 7d was recrystallized from toluene. Anal. Calc. for $\mathrm{C}_{29} \mathrm{H}_{27} \mathrm{BN}_{4} \mathrm{O}: \mathrm{C}, 75.99, \mathrm{H}, 5.94, \mathrm{~N}, 12.22$. Found: C, 76.20, H, 6.01, N, 12.15\%.

4-Methyl-6-(methylamino)-5-[(4-methylphenyl)diazenyl]-2,2-diphenyl-3H-1,3,2 $\lambda^{4}$-oxazaborine (6e). After column chromatography (silica gel $/ \mathrm{CH}_{2} \mathrm{Cl}_{2}$ or $n$-hexane/EtOAc) and boiling in ethanol $(4 \mathrm{~mL})$ for $5 \mathrm{~min}$, the title compound was obtained as yellow crystals. Yield $0.54 \mathrm{~g}$ (29\%, Method A, 72 h), $1.01 \mathrm{~g}$ (51\%, Method B, $72 \mathrm{~h})$, and $0.63 \mathrm{~g}$ (32\%, Method C, reflux 5 h), m.p. $173-176{ }^{\circ} \mathrm{C} .{ }^{1} \mathrm{H}-\mathrm{NMR}\left(\mathrm{CDCl}_{3}, 400 \mathrm{MHz}\right): \delta 11.95$ (br s, $\left.1 \mathrm{H}\right), 7.41-7.44(\mathrm{~m}, 6 \mathrm{H})$, 7.26-7.29 (m, 4H), 7.20-7.23 (m, 2H), 7.16-7.19 (m, 2H), 6.79 (br s, 1H), 3.11 (d, J = 4.4 Hz, 3H), 2.54 (s, 3H), 2.35 (s, 3H); ${ }^{13} \mathrm{C}-\mathrm{NMR}\left(\mathrm{CDCl}_{3}, 100 \mathrm{MHz}\right): \delta 169.4,161.6,150.5,149.8$ (br s), $137.2,131.7,129.7,127.4,126.4,120.5,115.3,26.3,21.2\left(2 \times \mathrm{CH}_{3}\right)$. For elemental analysis, compound $6 \mathbf{e}$ was recrystallized from the cyclohexane/toluene mixture. Anal. Calc. for $\mathrm{C}_{24} \mathrm{H}_{25} \mathrm{BN}_{4} \mathrm{O}$ : C, 72.74, H, 6.36, N, 14.14. Found: C, 73.13, H, 6.39, N, 14.45\%. HR-MS 
(MALDI), calc. for $\mathrm{C}_{24} \mathrm{H}_{26} \mathrm{BN}_{4} \mathrm{O}:[\mathrm{M}+\mathrm{H}]^{+}$397.2194, found: $397.2201[\mathrm{M}+\mathrm{H}]^{+}$; calc. for $\mathrm{C}_{24} \mathrm{H}_{26} \mathrm{BN}_{4} \mathrm{ONa}$ : $[\mathrm{M}+\mathrm{Na}]^{+} 419.2014$, found: $419.2022[\mathrm{M}+\mathrm{Na}]^{+}$; calc. for $\mathrm{C}_{24} \mathrm{H}_{26} \mathrm{BN}_{4} \mathrm{OK}$ : $[\mathrm{M}+\mathrm{K}]^{+}$435.1723, found $435.1753[\mathrm{M}+\mathrm{K}]^{+}$.

1,4-Dimethyl-2,2-diphenyl-5-[(4-methylphenyl)hydrazono]-1H-1,3,2 $\lambda^{4}$-diazaborine-4-one (7e). After column chromatography (silica gel $/ \mathrm{CH}_{2} \mathrm{Cl}_{2}$ ) and boiling for a few minutes in ethanol (4 mL), the title compound was obtained as yellow crystals. Yield $0.5 \mathrm{~g}(27 \%$, Method $\mathrm{A}, 72 \mathrm{~h})$ and $0.31 \mathrm{~g}(16 \%$, Method $\mathrm{C}$, reflux $5 \mathrm{~h})$, m.p. $148.5-151.5{ }^{\circ} \mathrm{C} .{ }^{1} \mathrm{H}-\mathrm{NMR}\left(\mathrm{CDCl}_{3}\right.$, $500 \mathrm{MHz}): \delta 15.6$ (s, 1H), 8.10 (br s, 1H), 7.40-7.41 (m, 4H), 7.30-7.33 (m, 4H), 7.22-7.27 (m, $4 \mathrm{H}), 7.16-7.18(\mathrm{~m}, 2 \mathrm{H}), 2.68(\mathrm{~s}, 3 \mathrm{H}), 2.48(\mathrm{~s}, 3 \mathrm{H}), 2.35(\mathrm{~s}, 3 \mathrm{H}) ;{ }^{13} \mathrm{C}-\mathrm{NMR}\left(\mathrm{CDCl}_{3}, 125 \mathrm{MHz}\right): \delta$ 170.4, 163.7, 147.7 (br s), 139.6, 135.1, 133.4, 130.2, 127.7, 126.7, 122.9, 115.8, 30.7, 21.2, 21.1. For elemental analysis, compound 7e was recrystallized from the cyclohexane/toluene mixture. Anal. Calc. for $\mathrm{C}_{24} \mathrm{H}_{25} \mathrm{BN}_{4} \mathrm{O}: \mathrm{C}, 72.74, \mathrm{H}, 6.36, \mathrm{~N}, 14.14$. Found: C, 72.49, H, 6.37, $\mathrm{N}, 14.30 \%$

5,N-Dimethyl-2-(4-methylphenyl)-3,3-diphenyl-4H-1,2,4,3 $\lambda^{4}$-triazaborine-6-carboxamide (8e). After column chromatography (silica gel $/ \mathrm{CH}_{2} \mathrm{Cl}_{2} \rightarrow$ EtOAc), the title compound was obtained as orange crystals. Yield $0.51 \mathrm{~g}(26 \%$, Method C, reflux $5 \mathrm{~h})$, m.p. $184-187{ }^{\circ} \mathrm{C}$. ${ }^{1} \mathrm{H}-\mathrm{NMR}\left(\mathrm{CDCl}_{3}, 500 \mathrm{MHz}\right): \delta 7.63$ (br s, 1H), 7.31-7.32 (m, 4H), 7.16-7.22 (m, 8H), $7.02(\mathrm{q}$, $J=5 \mathrm{~Hz}, 1 \mathrm{H}), 6.89-6.91(\mathrm{~m}, 2 \mathrm{H}), 2.83(\mathrm{~s}, J=5 \mathrm{~Hz}, 3 \mathrm{H}), 2.53(\mathrm{~s}, 3 \mathrm{H}), 2.21(\mathrm{~s}, 3 \mathrm{H})$; ${ }^{13} \mathrm{C}-\mathrm{NMR}$ $\left(\mathrm{CDCl}_{3}, 125 \mathrm{MHz}\right): \delta 164.9,158.8,147.1$ (br s), 145.3, 136.5, 133.6, 128.7, 127.5, 126.7, 123.0, 25.9, 23.8, 21.1. For elemental analysis, compound 8e was recrystallized from cyclohexane. Anal. Calc. for $\mathrm{C}_{24} \mathrm{H}_{25} \mathrm{BN}_{4} \mathrm{O}$ : C, 72.74, H, 6.36, N, 14.14. Found: C, 72.73, H, 6.37, N, 14.39\%.

6-(Methylamino)-5-[(4-methylphenyl)diazenyl]-2,2,4-triphenyl-3H-1,3,2 $\lambda^{4}$-oxazaborine (6f). After column chromatography (silica gel/ $\mathrm{CH}_{2} \mathrm{Cl}_{2}$ ) and recrystallization from the of ethanol/ toluene mixture, the title compound was obtained as yellow crystals. Yield $0.18 \mathrm{~g}(8 \%$, Method A, 96 h), $0.98 \mathrm{~g}$ (43\%, Method B, 72 h), and $0.48 \mathrm{~g}(21 \%$, Method C, reflux $2.5 \mathrm{~h})$, m.p. 228-230 ${ }^{\circ} \mathrm{C} .{ }^{1} \mathrm{H}-\mathrm{NMR}\left(\mathrm{CDCl}_{3}, 500 \mathrm{MHz}\right): \delta 12.09$ (br s, 1H), 7.61-7.63 (m, 2H), 7.49-7.52 (m, $5 \mathrm{H}), 7.44-7.47(\mathrm{~m}, 2 \mathrm{H}), 7.28-7.31(\mathrm{~m}, 4 \mathrm{H}), 7.21-7.23(\mathrm{~m}, 4 \mathrm{H}), 7.08-7.10(\mathrm{~m}, 2 \mathrm{H}), 6.84(\mathrm{~s}, 1 \mathrm{H})$, $3.20(\mathrm{~d}, J=4.9 \mathrm{~Hz}, 3 \mathrm{H}), 2.31(\mathrm{~s}, 3 \mathrm{H}) ;{ }^{13} \mathrm{C}-\mathrm{NMR}\left(\mathrm{CDCl}_{3}, 125 \mathrm{MHz}\right): \delta 168.8,163.1,150.3,149.7$ (br s), 137.4, 136.2, 131.8, 131.0, 129.8, 129.7, 128.1, 127.5, 126.5, 120.8, 115.2, 26.7, 21.3. Anal. Calc. for $\mathrm{C}_{29} \mathrm{H}_{27} \mathrm{BN}_{4} \mathrm{O}$ : C, 75.99, H, 5.94, N, 12.22. Found: C, 76.28, H, 6.08, N, 12.09\%.

3-Methyl-5-[(4-methylphenyl)hydrazono]-2,2,6-triphenyl-1H-1,3,2 $\lambda^{4}$-diazaborine-4-one (7f). After column chromatography (silica gel $/ \mathrm{CH}_{2} \mathrm{Cl}_{2}$ ) and recrystallization from the ethanol/

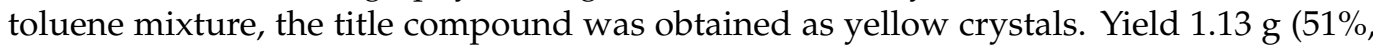
Method A, 96 h), $0.2 \mathrm{~g} \mathrm{(9 \% ,} \mathrm{Method} \mathrm{B,} 72$ h), and $0.3 \mathrm{~g} \mathrm{(13 \% ,} \mathrm{Method} \mathrm{C,} \mathrm{reflux} 2.5 \mathrm{~h})$, m.p. 238-240 ${ }^{\circ} \mathrm{C} .{ }^{1} \mathrm{H} \mathrm{NMR}\left(\mathrm{CDCl}_{3}, 500 \mathrm{MHz}\right): \delta 15.75(\mathrm{~s}, 1 \mathrm{H}), 8.12(\mathrm{~s}, 1 \mathrm{H}), 7.53-7.54(\mathrm{~m}, 3 \mathrm{H})$, 7.45-7.49 (m, 6H), 7.31-7.35 (m, 4H), 7.24-7.27 (m, 2H), 7.08-7.09 (m, 2H), 6.99-7.01 (m, 2H), 2.75 (s, 3H), 2.29 (s, 3H); ${ }^{13} \mathrm{C}-\mathrm{NMR}\left(\mathrm{CDCl}_{3}, 125 \mathrm{MHz}\right): \delta 169.5,164.4,148.1$ (br), 139.5, 135.3, $134.1,133.4,131.9,130.2,129.4,128.5,127.8,126.6,122.2,115.9,30.9,21.1$. Anal. Calc. for $\mathrm{C}_{29} \mathrm{H}_{27} \mathrm{BN}_{4} \mathrm{O}: \mathrm{C}, 75.99, \mathrm{H}, 5.94, \mathrm{~N}, 12.22$. Found: C, 76.16, H, 6.11, N, $12.49 \%$.

4-Methyl-6-[1-(methylamino)ethyliden]-2-(4-methylphenyl)-3,3-diphenyl-1,2,4,3 $\lambda^{4}$-triazaborine5-one (5g). After column chromatography (Method A: silica gel/n-hexan $\rightarrow \mathrm{CH}_{2} \mathrm{Cl}_{2} / \mathrm{n}$ hexan (1:4) $\rightarrow \mathrm{CH}_{2} \mathrm{Cl}_{2} \rightarrow$ EtOAc, Method C: silica gel/n-hexane/EtOAc (15:1) $\rightarrow$ EtOAc), the title compound was obtained as yellow crystals. Yield $0.53 \mathrm{~g}$ (26\%, Method A, $72 \mathrm{~h}$ ), $0.56 \mathrm{~g}$ (30\%, Method B, $72 \mathrm{~h})$, and $0.99 \mathrm{~g}$ (48\%, Method C, reflux $4 \mathrm{~h})$, m.p. $193-196{ }^{\circ} \mathrm{C}$. ${ }^{1} \mathrm{H}-\mathrm{NMR}\left(\mathrm{CDCl}_{3}, 500 \mathrm{MHz}\right): \delta 13.88$ (br q, $\left.J=4.5 \mathrm{~Hz}, 1 \mathrm{H}\right), 7.45-7.47(\mathrm{~m}, 4 \mathrm{H}), 7.20-7.22(\mathrm{~m}$, $4 \mathrm{H}), 7.13-7.15(\mathrm{~m}, 2 \mathrm{H}), 7.08-7.1(\mathrm{~m}, 2 \mathrm{H}), 6.82-6.83(\mathrm{~m}, 2 \mathrm{H}), 3.08(\mathrm{~d}, J=5.4 \mathrm{~Hz}, 3 \mathrm{H}), 2.57(\mathrm{~s}$, 3H), 2.43 (s, 3H), $2.16(\mathrm{~s}, 3 \mathrm{H}) ;{ }^{13} \mathrm{C}-\mathrm{NMR}\left(\mathrm{CDCl}_{3}, 125 \mathrm{MHz}\right): \delta 174.6,161.1,147.5$ (br), 146.3, 136.0, 134.0, 128.3, 127.1, 125.8, 123.0, 122.8, 31.5, 30.5, 20.9, 13.6. For elemental analysis, compound $5 \mathrm{~g}$ was recrystallized from the cyclohexane/toluene mixture. Anal. Calc. for $\mathrm{C}_{25} \mathrm{H}_{27} \mathrm{BN}_{4} \mathrm{O}: \mathrm{C}, 73.18, \mathrm{H}, 6.63, \mathrm{~N}, 13.65$. Found: $\mathrm{C}, 73.39, \mathrm{H}, 6.73, \mathrm{~N}, 13.56 \%$.

3,4-Dimethyl-6-(methylamino)-5-[(4-methylphenyl)diazenyl]-2,2-diphenyl-1,3,2 $\lambda^{4}$-oxazaborine (6g). After column chromatography (see 5g) and recrystallization from the ethanol/toluene mixture, the title compound was obtained as yellow crystals. Yield $0.65 \mathrm{~g} \mathrm{(32 \% ,} \mathrm{Method} \mathrm{A,}$ $72 \mathrm{~h}), 0.32 \mathrm{~g}(17 \%$, Method B, $72 \mathrm{~h})$ and $0.11 \mathrm{~g}(5.4 \%$, Method C, reflux $4 \mathrm{~h})$, m.p. $215.5-221{ }^{\circ} \mathrm{C}$. 
${ }^{1} \mathrm{H}-\mathrm{NMR}\left(\mathrm{CDCl}_{3}, 500 \mathrm{MHz}\right): \delta 12.22(\mathrm{br} \mathrm{s}, 1 \mathrm{H}), 7.41-7.43(\mathrm{~m}, 2 \mathrm{H}), 7.38-7.39(\mathrm{~m}, 4 \mathrm{H}), 7.27-$ $7.30(\mathrm{~m}, 4 \mathrm{H}), 7.22-7.25(\mathrm{~m}, 2 \mathrm{H}), 7.16-7.17(\mathrm{~m}, 2 \mathrm{H}), 2.99(\mathrm{~s}, 3 \mathrm{H}), 2.64(\mathrm{~s}, 3 \mathrm{H}), 2.35(\mathrm{~s}, 3 \mathrm{H})$; ${ }^{13} \mathrm{C}-\mathrm{NMR}\left(\mathrm{CDCl}_{3}, 125 \mathrm{MHz}\right): \delta 170.1,161.3,150.7,148.3(\mathrm{br}), 136.6,133.1,129.7,127.3$, $126.5,120.3,116.2,37.6,26.3,21.3,15.2$. HR-MS (MALDI), calc. for $\mathrm{C}_{25} \mathrm{H}_{28} \mathrm{BN}_{4} \mathrm{O}:[\mathrm{M}+\mathrm{H}]^{+}$ 411.2351, found: $411.2358[\mathrm{M}+\mathrm{H}]^{+}$; calc. for $\mathrm{C}_{25} \mathrm{H}_{27} \mathrm{BN}_{4} \mathrm{ONa}$ : $[\mathrm{M}+\mathrm{Na}]^{+} 433.2170$, found: $433.2178[\mathrm{M}+\mathrm{Na}]^{+}$; calc. for $\mathrm{C}_{19} \mathrm{H}_{22} \mathrm{BN}_{4} \mathrm{O}:[\mathrm{M}+\mathrm{H}-\mathrm{Ph}]^{+}$333.1881, found: 333.1886 $[\mathrm{M}+\mathrm{H}-\mathrm{Ph}]^{+}$.

1,3,6-Trimethyl-5-[(4-methylphenyl)hydrazono]-2,2-diphenyl-1,3,2 $\lambda^{4}$-diazaborine-4-one (7g). After column chromatography (see $\mathbf{5 g}$ ) and recrystallization from the ethanol/toluene mixture, the title compound was obtained as yellow crystals. Yield $0.13 \mathrm{~g}(6.3 \%$, Method C, reflux 4 h), m.p. $263.5-266{ }^{\circ} \mathrm{C} .{ }^{1} \mathrm{H}-\mathrm{NMR}\left(\mathrm{CDCl}_{3}, 500 \mathrm{MHz}\right): \delta 15.59(\mathrm{~s}, 1 \mathrm{H}), 7.47-7.48(\mathrm{~m}$, $4 \mathrm{H}), 7.31-7.34(\mathrm{~m}, 4 \mathrm{H}), 7.24-7.28(\mathrm{~m}, 4 \mathrm{H}), 7.17-7.19(\mathrm{~m}, 2 \mathrm{H}), 3.01(\mathrm{~s}, 3 \mathrm{H}), 2.56(\mathrm{~s}, 3 \mathrm{H}), 2.53(\mathrm{~s}$, $3 \mathrm{H}), 2.35(\mathrm{~s}, 3 \mathrm{H}) ;{ }^{13} \mathrm{C}-\mathrm{NMR}\left(\mathrm{CDCl}_{3}, 125 \mathrm{MHz}\right): \delta 171.2,163.0,146.3(\mathrm{br}), 140.0,134.6,133.9$, $130.2,127.7,126.6,123.8,115.6,39.7,30.5,21.1,15.4$. Anal. Calc. for $\mathrm{C}_{25} \mathrm{H}_{27} \mathrm{BN}_{4} \mathrm{O}: \mathrm{C}, 73.18$, $\mathrm{H}, 6.63, \mathrm{~N}, 13.65$. Found: C, 73.58, H, 6.64, N, 13.43\%.

N,4,5-Trimethyl-2-(4-methylphenyl)-3,3-diphenyl-1,2,4,3 $\lambda^{4}$-triazaborine-6-carboxamide (8g). After column chromatography (silica gel/n-hexane/EtOAc (15:1) $\rightarrow$ EtOAc) and boiling in ethanol $(2 \mathrm{~mL})$ for $5 \mathrm{~min}$, the title compound was obtained as dark yellow crystals. Yield $0.05 \mathrm{~g}\left(2.4 \%\right.$, Method C, reflux 4 h), m.p. $186-189{ }^{\circ} \mathrm{C} .{ }^{1} \mathrm{H}-\mathrm{NMR}\left(\mathrm{CDCl}_{3}, 500 \mathrm{MHz}\right): \delta 7.30$ $7.31(\mathrm{~m}, 4 \mathrm{H}), 7.16-7.22(\mathrm{~m}, 6 \mathrm{H}), 7.08(\mathrm{br} \mathrm{q}, J=4.9 \mathrm{~Hz}, 1 \mathrm{H}), 7.00-7.02(\mathrm{~m}, 2 \mathrm{H}), 6.86-6.88(\mathrm{~m}$, $2 \mathrm{H}), 3.00(\mathrm{~s}, 3 \mathrm{H}), 2.87(\mathrm{~d}, J=4.9 \mathrm{~Hz}, 3 \mathrm{H}), 2.65(\mathrm{~s}, 3 \mathrm{H}) ;{ }^{13} \mathrm{C}-\mathrm{NMR}\left(\mathrm{CDCl}_{3}, 100 \mathrm{MHz}\right): \delta 165.2$, 159.5, 145.8, 145.6 (br), 135.7, 134.0, 128.9, 128.4, 127.5, 126.6, 123.4, 39.1, 26.1, 21.0, 17.8; ${ }^{11} \mathrm{~B}-\mathrm{NMR}\left(\mathrm{CDCl}_{3}, 128 \mathrm{MHz}\right): \delta 0.98$. HR-MS (MALDI), calc. for $\mathrm{C}_{25} \mathrm{H}_{28} \mathrm{BN}_{4} \mathrm{O}:[\mathrm{M}+\mathrm{H}]^{+}$ 411.2356, found: $411.2358[\mathrm{M}+\mathrm{H}]^{+}$; calc. for $\mathrm{C}_{25} \mathrm{H}_{27} \mathrm{BN}_{4} \mathrm{ONa}$ : $[\mathrm{M}+\mathrm{Na}]^{+} 433.2176$, found: 433.2178 [M + Na] $]^{+}$; calc. for $\mathrm{C}_{25} \mathrm{H}_{27} \mathrm{BN}_{4} \mathrm{OK}:[\mathrm{M}+\mathrm{K}]^{+} 449.1915$, found: $449.1918[\mathrm{M}+\mathrm{K}]^{+}$; calc. for $\mathrm{C}_{19} \mathrm{H}_{22} \mathrm{BN}_{4} \mathrm{O}:[\mathrm{M}+\mathrm{H}-\mathrm{Ph}]^{+} 333.1887$, found: $333.1887[\mathrm{M}+\mathrm{H}-\mathrm{Ph}]^{+}$.

4,7,8-Trimethyl-2-(4-methylphenyl)-3,3,6,6-tetraphenyl-4,6-dihydro-3H-2 $2 \lambda^{4}, 3 \lambda^{4}, 6 \lambda^{4}, 7 \lambda^{4}$ -[1,3,2]oxazaborinino[6,5-e][1,2,4,3]triazaborinine (9g). After column chromatography (silica gel/n-hexane $\rightarrow \mathrm{CH}_{2} \mathrm{Cl}_{2} \rightarrow$ EtOAc) and boiling in ethanol $(2 \mathrm{~mL})$ for $5 \mathrm{~min}$, the title compound was obtained as yellow crystals. Yield $0.11 \mathrm{~g}(4 \%$, Method A, $72 \mathrm{~h}), \mathrm{m} . \mathrm{p}$. 217-218 ${ }^{\circ} \mathrm{C} .{ }^{1} \mathrm{H}-\mathrm{NMR}\left(\mathrm{CDCl}_{3}, 500 \mathrm{MHz}\right): 87.39-7.40(\mathrm{~m}, 4 \mathrm{H}), 7.33-7.35(\mathrm{~m}, 4 \mathrm{H}), 7.26-7.30$ $(\mathrm{m}, 6 \mathrm{H}), 7.17-7.22(\mathrm{~m}, 6 \mathrm{H}), 7.08-7.10(\mathrm{~m}, 2 \mathrm{H}), 6.82-6.84(\mathrm{~m}, 2 \mathrm{H}), 3.08(\mathrm{~s}, 3 \mathrm{H}), 2.66(\mathrm{~s}, 3 \mathrm{H}), 2.54$ $(\mathrm{s}, 3 \mathrm{H}), 2.16(\mathrm{~s}, 3 \mathrm{H}) ;{ }^{13} \mathrm{C}-\mathrm{NMR}\left(\mathrm{CDCl}_{3}, 125 \mathrm{MHz}\right): \delta 169.3,155.8,146.8$ (br), 145.6 (br), 145.5, 136.2, 134.1, 132.9, 128.6, 127.6, 127.5, 126.9, 126.5, 122.9, 120.0, 38.6, 31.9, 21.0, 15.1. HR-MS (MALDI), calc. for $\mathrm{C}_{37} \mathrm{H}_{37} \mathrm{~B}_{2} \mathrm{~N}_{4} \mathrm{O}:[\mathrm{M}+\mathrm{H}]^{+} 575.3148$, found: $575.3160[\mathrm{M}+\mathrm{H}]^{+}$; calc. for $\mathrm{C}_{37} \mathrm{H}_{36} \mathrm{~B}_{2} \mathrm{~N}_{4} \mathrm{ONa}$ : $[\mathrm{M}+\mathrm{Na}]^{+}$597.2967, found: 597.2979 [M + Na ${ }^{+}$; calc. for $\mathrm{C}_{31} \mathrm{H}_{31} \mathrm{~B}_{2} \mathrm{~N}_{4} \mathrm{O}$ : $[\mathrm{M}+\mathrm{H}-\mathrm{Ph}]^{+}$497.2679, found: $497.2692[\mathrm{M}+\mathrm{H}-\mathrm{Ph}]^{+}$.

4-Methyl-6-[(methylamino)(phenyl)methylidene]-2-(4-methylphenyl)-3,3-diphenyl-1,2,4,3 $\lambda^{4}$ triazaborine-5-one (5h). After column chromatography (silica gel/ $\mathrm{CH}_{2} \mathrm{Cl}_{2}$ ) and boiling in ethanol $(5 \mathrm{~mL})$ for $5 \mathrm{~min}$, the title compound was obtained as yellow crystals. Yield $0.35 \mathrm{~g}$ (14.8\%, Method C, reflux 3 h), m.p. 206-211 ${ }^{\circ} \mathrm{C} .{ }^{1} \mathrm{H}-\mathrm{NMR}\left(\mathrm{CDCl}_{3}, 500 \mathrm{MHz}\right): \delta 13.80$ (br $\mathrm{q}, J=4.6 \mathrm{~Hz}, 1 \mathrm{H}), 7.45-7.49(\mathrm{~m}, 7 \mathrm{H}), 7.29-7.30(\mathrm{~m}, 2 \mathrm{H}), 7.20-7.23(\mathrm{~m}, 4 \mathrm{H}), 7.13-7.15(\mathrm{~m}$, $2 \mathrm{H}), 6.80-6.82(\mathrm{~m}, 2 \mathrm{H}), 6.61-6.63(\mathrm{~m}, 2 \mathrm{H}), 2.94(\mathrm{~d}, J=5.4 \mathrm{~Hz}, 3 \mathrm{H}), 2.60(\mathrm{~s}, 3 \mathrm{H}), 2.03(\mathrm{~s}, 3 \mathrm{H})$; ${ }^{13} \mathrm{C}-\mathrm{NMR}\left(\mathrm{CDCl}_{3}, 125 \mathrm{MHz}\right): \delta 174.4,161.1,147.4$ (br), 145.7, 135.8, 133.9, 130.4, 130.2, 128.4, $128.3,128.1,127.2,125.9,123.3,122.4,33.1,30.5,20.8$. For elemental analysis, compound 5h was recrystallized from ethyl acetate. Anal. Calc. for $\mathrm{C}_{30} \mathrm{H}_{29} \mathrm{BN}_{4} \mathrm{O}: \mathrm{C}, 76.28, \mathrm{H}, 6.19, \mathrm{~N}$, 11.86. Found: C, $76.31, \mathrm{H}, 6.27, \mathrm{~N}, 11.68 \%$.

3-Methyl-6-(methylamino)-5-[(4-methylphenyl)diazenyl]-2,2,4-triphenyl-1,3,2 $\lambda^{4}$-oxazaborine (6h). After flash chromatography (n-hexane $\rightarrow$ chloroform) and washing with cyclohexane, the title compound was obtained as yellow crystals. Yield $0.53 \mathrm{~g}(22 \%$, Method A, $96 \mathrm{~h})$, m.p. 187-189.5 ${ }^{\circ} \mathrm{C} .{ }^{1} \mathrm{H}-\mathrm{NMR}\left(\mathrm{CDCl}_{3}, 500 \mathrm{MHz}\right): \delta 11.94$ (br s, $\left.1 \mathrm{H}\right), 7.42-7.50(\mathrm{~m}, 7 \mathrm{H}), 7.30-7.33$ $(\mathrm{m}, 6 \mathrm{H}), 7.24-7.27(\mathrm{~m}, 2 \mathrm{H}), 6.94-7.00(\mathrm{~m}, 4 \mathrm{H}), 3.05(\mathrm{~d}, J=4.5 \mathrm{~Hz}, 3 \mathrm{H}), 2.76(\mathrm{~s}, 3 \mathrm{H}), 2.25(\mathrm{~s}$, $3 \mathrm{H}) ;{ }^{13} \mathrm{C}-\mathrm{NMR}\left(\mathrm{CDCl}_{3}, 125 \mathrm{MHz}\right): \delta 171.4,162.1,150.4,148.1$ (br), 136.7, 134.7, 133.1, 129.5, $128.8,128.2,128.1,127.4,126.6,120.3,117.0,39.4,26.5,21.2$. HR-MS (MALDI), calc. for 
$\mathrm{C}_{25} \mathrm{H}_{28} \mathrm{BN}_{4} \mathrm{O}:[\mathrm{M}+\mathrm{H}]^{+} 473.25072$, found: $473.25162[\mathrm{M}+\mathrm{H}]^{+}$; calc. for $\mathrm{C}_{25} \mathrm{H}_{27} \mathrm{BN}_{4} \mathrm{ONa}$ : $[\mathrm{M}+\mathrm{Na}]^{+} 495.2327$, found: $495.2335\left[\mathrm{M}+\mathrm{Na}^{+}\right.$; calc. for $\mathrm{C}_{25} \mathrm{H}_{27} \mathrm{BN}_{4} \mathrm{OK}:[\mathrm{M}+\mathrm{K}]^{+} 511.2066$, found: $511.2075[\mathrm{M}+\mathrm{K}]^{+}$.

1,3-Dimethyl-5-[(4-methylphenyl)hydrazono]-2,2,6-triphenyl-1,3,2 $\lambda^{4}$-diazaborine-4-one (7h). After column chromatography (silica gel $/ \mathrm{CH}_{2} \mathrm{Cl}_{2}$ ) and boiling in ethanol $(5 \mathrm{~mL})$ for $5 \mathrm{~min}$, the title compound was obtained as yellow crystals. Yield $0.37 \mathrm{~g}(16 \%$, Method C, reflux $3 \mathrm{~h}$ ) with m.p. $160.5-163.5^{\circ} \mathrm{C}$. After flash chromatography (n-hexane $\rightarrow$ chloroform) and boiling in ethanol, the title compound was obtained as yellow crystals. Yield $0.07 \mathrm{~g}(3 \%$, Method A, 96 h). ${ }^{1} \mathrm{H}-\mathrm{NMR}\left(\mathrm{CDCl}_{3}, 500 \mathrm{MHz}\right): \delta 15.43(\mathrm{~s}, 1 \mathrm{H}), 7.57-7.59(\mathrm{~m}, 4 \mathrm{H}), 7.49-7.50$ $(\mathrm{m}, 3 \mathrm{H}), 7.35-7.38(\mathrm{~m}, 4 \mathrm{H}), 7.27-7.30(\mathrm{~m}, 2 \mathrm{H}), 7.22-7.24(\mathrm{~m}, 2 \mathrm{H}), 7.00-7.01(\mathrm{~m}, 2 \mathrm{H}), 6.76-6.77$ $(\mathrm{m}, 2 \mathrm{H}), 2.78(\mathrm{~s}, 3 \mathrm{H}), 2.61(\mathrm{~s}, 3 \mathrm{H}), 2.25(\mathrm{~s}, 3 \mathrm{H}) ;{ }^{13} \mathrm{C}-\mathrm{NMR}\left(\mathrm{CDCl}_{3}, 125 \mathrm{MHz}\right): \delta 172.1,163.3$, 146.2 (br), 139.8, 134.6, 133.9, 133.1, 130.1, 129.5, 128.4, 127.7, 127.5, 126.6, 124.8, 115.4, 41.0, 30.5, 21.0. For elemental analysis, compound $7 \mathrm{~h}$ was recrystallized from ethyl acetate. Anal. Calc. for $\mathrm{C}_{30} \mathrm{H}_{29} \mathrm{BN}_{4} \mathrm{O}: \mathrm{C}, 76.28, \mathrm{H}, 6.19, \mathrm{~N}, 11.86$. Found: C, 76.56, H, 6.24, N, $11.75 \%$.

5,N-Dimethyl-2-(4-methylphenyl)-3,3-diphenyl-1,2,4,3 $\lambda^{4}$-triazaborine-6-carboxamide (8h). After column chromatography (silica gel $/ \mathrm{CH}_{2} \mathrm{Cl}_{2}$ ) and boiling in ethanol $(5 \mathrm{~mL})$ for $5 \mathrm{~min}$, the title compound was obtained as orange crystals. Yield $0.51 \mathrm{~g}(21 \%$, Method C, reflux 3 h), m.p. $207.5-209{ }^{\circ} \mathrm{C} .{ }^{1} \mathrm{H}-\mathrm{NMR}\left(\mathrm{CDCl}_{3}, 500 \mathrm{MHz}\right): \delta 7.41-7.48(\mathrm{~m}, 3 \mathrm{H}), 7.34-7.36(\mathrm{~m}, 4 \mathrm{H})$, 7.18-7.24 (m, 8H), 7.10-7.12 (m, 2H), $6.96(\mathrm{br} \mathrm{q}, J=5 \mathrm{~Hz}, 1 \mathrm{H}), 6.92-6.93(\mathrm{~m}, 2 \mathrm{H}), 2.78(\mathrm{~s}, 3 \mathrm{H})$, $2.72(\mathrm{~d}, J=5 \mathrm{~Hz}, 3 \mathrm{H}), 2.25(\mathrm{~s}, 3 \mathrm{H}) ;{ }^{13} \mathrm{C}-\mathrm{NMR}\left(\mathrm{CDCl}_{3}, 125 \mathrm{MHz}\right): \delta 163.9,159.0,145.8,145.4$ (br s), 136.3, 134.5, 134.1, 129.38, 129.36, 128.7, 128.5, 127.6, 126.7, 126.5, 123.8, 40.6, 26.0, 21.1. For elemental analysis, compound $\mathbf{8 h}$ was recrystallized from ethyl acetate. Anal. Calc. for $\mathrm{C}_{30} \mathrm{H}_{29} \mathrm{BN}_{4} \mathrm{O}: \mathrm{C}, 76.28, \mathrm{H}, 6.19, \mathrm{~N}, 11.86$. Found: $\mathrm{C}, 76.24, \mathrm{H}, 6.28, \mathrm{~N}, 11.75 \%$.

4,7-Dimethyl-2-(4-methylphenyl)-3,3,6,6,8-pentaphenyl-4,6-dihydro-3H-2 $\lambda^{4}, 3 \lambda^{4}, 6 \lambda^{4}, 7 \lambda^{4}$ -[1,3,2]oxazaborinino[6,5-e][1,2,4,3]triazaborinine (9h). After column chromatography (silica gel/n-hexane $\rightarrow \mathrm{CH}_{2} \mathrm{Cl}_{2} \rightarrow$ EtOAc) and recrystallization from cyclohexane (or boiling in acetic acid), the title compound was obtained as yellow crystals. Yield $0.45 \mathrm{~g}(15 \%$, Method A, 96 h), $0.11 \mathrm{~g}\left(3 \%\right.$, Method C, reflux 3 h), m.p. $216-217{ }^{\circ} \mathrm{C} .{ }^{1} \mathrm{H}-\mathrm{NMR}\left(\mathrm{CDCl}_{3}, 500 \mathrm{MHz}\right)$ : 反 7.39-7.40 (m, 4H), 7.45-7.52 (m, 7H), 7.27-7.39 (m, 12H), 7.16-7.23 (m, 6H), 6.77-6.79 $(\mathrm{m}, 2 \mathrm{H}), 6.63-6.65(\mathrm{~m}, 2 \mathrm{H}), 2.93(\mathrm{~s}, 3 \mathrm{H}), 2.70(\mathrm{~s}, 3 \mathrm{H}), 2.07$ (s, 3H); ${ }^{13} \mathrm{C}-\mathrm{NMR}\left(\mathrm{CDCl}_{3}, 125\right.$ $\mathrm{MHz}$ : $\delta 170.3,156.3,146.9$ (br), 145.3 (br), 145.2, 135.9, 134.0, 132.9, 132.4, 129.9, 128.6, 128.4, 128.1, 127.7, 127.6, 127.0, 126.5, 122.2, 120.8, 40.5, 31.8, 20.9. HR-MS (MALDI), calc. for $\mathrm{C}_{42} \mathrm{H}_{39} \mathrm{~B}_{2} \mathrm{~N}_{4} \mathrm{O}:[\mathrm{M}+\mathrm{H}]^{+}$637.3304, found: $5637.3318[\mathrm{M}+\mathrm{H}]^{+}$; calc. for $\mathrm{C}_{42} \mathrm{H}_{38} \mathrm{~B}_{2} \mathrm{~N}_{4} \mathrm{ONa}$ : $[\mathrm{M}+\mathrm{Na}]^{+}$659.3124, found: $659.3136[\mathrm{M}+\mathrm{Na}]^{+}$; calc. for $\mathrm{C}_{36} \mathrm{H}_{33} \mathrm{~B}_{2} \mathrm{~N}_{4} \mathrm{O}:[\mathrm{M}+\mathrm{H}-\mathrm{Ph}]^{+}$ 559.2835, found: $559.2851[\mathrm{M}+\mathrm{H}-\mathrm{Ph}]^{+}$.

Rearrangement of oxazaborines $\mathbf{6 a}, \mathbf{6} \mathbf{e}-\mathbf{h}$. The appropriate oxazaborine $\mathbf{6 a}, \mathbf{6} \mathbf{e}-\mathbf{h}$ was heated at $200-250{ }^{\circ} \mathrm{C}$, and the reaction was monitored by TLC with dichloromethane as the eluent. The residue was subjected to column chromatography on silica gel $\left(\mathrm{CH}_{2} \mathrm{Cl}_{2}\right)$.

5-[(4-Methylphenyl)hydrazono]-2,2-diphenyl-1H-1,3,2 $\lambda^{4}$-diazaborine-4-one (7a). Oxazaborine $6 \mathrm{a}(0.99 \mathrm{~g}, 2.59 \mathrm{mmol})$ was used. After $6 \mathrm{~min}$ at $250{ }^{\circ} \mathrm{C}$, the crude mixture was dissolved in dichloromethane. An amount of $0.42 \mathrm{~g}$ was not dissolved in dichloromethane, and according to ${ }^{1} \mathrm{H}$ NMR it was found that it was pure diazaborinone $7 \mathrm{a}$. After column chromatography, the title compound was obtained as yellow crystals $(0.39 \mathrm{~g})$. Total yield $0.81 \mathrm{~g} \mathrm{(82 \% ),} \mathrm{m.p.} 263.5-266^{\circ} \mathrm{C} .{ }^{1} \mathrm{H}-\mathrm{NMR}\left(\mathrm{CDCl}_{3}, 500 \mathrm{MHz}\right): \delta 15.29$ (br s, $\left.1 \mathrm{H}\right), 8.39$ (br s, $1 \mathrm{H}), 7.349-7.35(\mathrm{~m}, 4 \mathrm{H}), 7.27-7.29(\mathrm{~m}, 4 \mathrm{H}), 7.21-7.24(\mathrm{~m}, 4 \mathrm{H}), 7.17-7.20(\mathrm{~m}, 2 \mathrm{H}), 5.73(\mathrm{br} \mathrm{s}$, $1 \mathrm{H}), 2.53(\mathrm{~s}, 3 \mathrm{H}), 2.35(\mathrm{~s}, 3 \mathrm{H}) ;{ }^{13} \mathrm{C}-\mathrm{NMR}\left(\mathrm{CDCl}_{3}, 125 \mathrm{MHz}\right): \delta 171.2,164.0,149.7(\mathrm{br}), 139.4$, 135.6, 132.4, 130.3, 127.8, 126.6, 122.8, 116.0, 21.3, 21.1. Anal. Calc. for $\mathrm{C}_{13} \mathrm{H}_{23} \mathrm{BN}_{4} \mathrm{O}: \mathrm{C}, 72.27$ H, 6.06, N, 14.64. Found: C, 72.47, H, 5.99, N, 14.54\%.

Diazaborinone 7e. Oxazaborine $6 \mathrm{e}(0.79 \mathrm{~g}, 2 \mathrm{mmol})$ was used: $25 \mathrm{~min}$ at $200{ }^{\circ} \mathrm{C}$ and $25 \mathrm{~min}$ at $250^{\circ} \mathrm{C}$. After column chromatography, the title compound was obtained as yellow crystals. Yield $0.5 \mathrm{~g}(63 \%)$.

Diazaborinone 7f. Oxazaborine $6 \mathrm{f}(0.92 \mathrm{~g}, 2 \mathrm{mmol})$ was used: $70 \mathrm{~min}$ at $250{ }^{\circ} \mathrm{C}$. After column chromatography, the title compound was obtained as yellow crystals. Yield $0.45 \mathrm{~g}(49 \%)$. 
Diazaborinone $7 \mathrm{~g}$. Oxazaborine $6 \mathrm{~g}(0.82 \mathrm{~g}, 2 \mathrm{mmol})$ was used: $30 \mathrm{~min}$ at $250{ }^{\circ} \mathrm{C}$. After column chromatography, the title compound was obtained as yellow crystals. Yield $0.64 \mathrm{~g}(78 \%)$.

Diazaborinone $7 \mathrm{~h}$. Oxazaborine $6 \mathrm{~h}(0.74 \mathrm{~g}, 0.74 \mathrm{mmol})$ was used: $90 \mathrm{~min}$ at $230{ }^{\circ} \mathrm{C}$. After column chromatography, the title compound was obtained as yellow crystals. Yield $0.2 \mathrm{~g}(57 \%)$.

\section{Conclusions}

The novel boron containing heterocyclic compounds-triazaborinones $\mathbf{5 a}-\mathbf{d}, \mathbf{5} \mathbf{g}$, and $5 \mathrm{~h}$-were synthesized from the reaction of simple $\beta$-enaminoamides and 4-methylbenzenediazonium tetraphenylborate. Other products that were formed during the reaction were oxazaborines $\mathbf{6 a}, \mathbf{6 e}, \mathbf{6 f}$, and $\mathbf{6 g}$; diazaborinones $\mathbf{7 b}-\mathbf{h}$; and triazaborines $8 \mathbf{e}, 8 \mathrm{~g}$, and $\mathbf{8 h}$. Heating $\left(250^{\circ} \mathrm{C}, 6-70 \mathrm{~min}\right)$ of oxazaborines 6 without solvent resulted in their transformation into diazaborinones $\mathbf{7 a}-\mathbf{h}$ in $49-82 \%$ yields. Compound $\mathbf{7 a}$ was not formed by the reaction of enaminoamide 1a and diazonium tetraphenylborate, but it was formed by ring transformation of oxazaborine 6a. Although $N$-phenylenaminoamides 1 $\left(\mathrm{R}^{3}=\mathrm{Ph}\right)$ previously used produced diazaborinones only when there was an $-\mathrm{NH}_{2}$ group at position 3 of $N$-phenylenaminoamide, the enaminoamides $\mathbf{1}\left(\mathrm{R}^{3}=\mathrm{H}\right.$ or $\left.\mathrm{Me}\right)$ used in this work gave diazaborinones even when there was -NHMe at position 3 of the enaminoamide.

Structural, spectral, and crystallographic properties of the prepared structures were studied. Triazaborinones $\mathbf{5 c}$ and $\mathbf{5 d}$ and oxazaborine $\mathbf{6 a}$ form dimers in the solid state. There are hydrophobic cavities in the structure of triazaborinone $\mathbf{5 d}$ in which toluene as a solvent is enclosed. The measured quantum yields of the fluorescence in the solid-state of selected compounds are not very high; for diazaborinone $7 \mathbf{a}, 14.62 \%$ is the best.

Supplementary Materials: The following supporting information can be downloaded at, Scheme S1: Preparation of starting compounds; ${ }^{1} \mathrm{H},{ }^{13} \mathrm{C},{ }^{11} \mathrm{~B}$, and ${ }^{15} \mathrm{~N}$ NMR spectra of heterocyclic compounds 5-9: Figures S1-S111; UV-Vis spectra: Figures S112-S124; Table S1: UV-Vis parameters of prepared heterocyclic compounds in $\mathrm{CH}_{2} \mathrm{Cl}_{2}$; Table S2: UV-Vis parameters of triazaborine $5 \mathrm{~g}$; Table S3: UV-Vis parameters of oxazaborine $6 \mathbf{g}$; Table S4: UV-Vis parameters of diazaborinone 7a; Table S5: Crystal Data; Crystallographic data: Figures S125-S136; Fluorescence: Figures S137-S139.

Author Contributions: Conceptualization, M.S. (Markéta Svobodová); methodology, M.S. (Markéta Svobodová); validation, M.S. (Markéta Svobodová) and J.S.; analysis, M.S. (Markéta Svobodová), J.S., V.B., L.M., and B.-H.L.; investigation, M.S. (Markéta Svobodová), L.S., and L.M.; data curation, M.S. (Markéta Svobodová), J.S., V.B., and B.-H.L.; writing-original draft preparation, M.S. (Markéta Svobodová), J.S., M.S. (Miloš Sedlák), and B.-H.L.; writing-review and editing, M.S. (Markéta Svobodová), J.S., M.S. (Miloš Sedlák), and B.-H.L.; visualization, M.S. (Markéta Svobodová) and J.S.; supervision, M.S. (Miloš Sedlák) All authors have read and agreed to the published version of the manuscript.

Funding: This research was funded by the Ministry of Education, Youth and Sports of the Czech Republic.

Institutional Review Board Statement: Not applicable.

Informed Consent Statement: Not applicable.

Data Availability Statement: The data presented are available in the manuscript Supplementary Materials. The data files in cif format for the crystal structures in this paper can be requested from the Cambridge Structural Database. CCDC 2127610-2127615 contains the supplementary crystallographic data for this paper. These data can be obtained free of charge from The Cambridge Crystallographic Data Centre via www.ccdc.cam.ac.uk/structures (accessed on 3 December 2021).

Conflicts of Interest: The authors declare no conflict of interest.

Sample Availability: Samples of the compounds 6-9 are available from the authors. 


\section{References}

1. Mai, A.; Perrone, A.; Nebbioso, A.; Rotili, D.; Valente, S.; Tardugno, M.; Massa, S.; De Bellis, F.; Altucci, L. Novel Uracil-Based 2-Aminoanilide and 2-Aminoanilide-like Derivatives: Histone Deacetylase Inhibition and in-Cell Activities. Bioorg. Med. Chem. Lett. 2008, 18, 2530-2535. [CrossRef] [PubMed]

2. Zandersons, A.; Lusis, V.; Vigante, B.; Mutsenietse, D.; Dubur, G. Synthesis of Ethoxycarbonyl-1,4- and -1,2-Dihydropyridinecarboxylic Acid Amides. Chem. Heterocycl. Compd. 1991, 27, 1339-1347. [CrossRef]

3. Cooper, K.; Fray, M.J.; Parry, M.J.; Richardson, K.; Steele, J. 1,4-Dihydropyridines as Antagonists of Platelet Activating Factor. 1. Synthesis and Structure-Activity Relationships of 2-(4-Heterocyclyl)Phenyl Derivatives. J. Med. Chem. 1992, 35, 3115-3129. [CrossRef] [PubMed]

4. Wong, W.C.; Chiu, G.; Wetzel, J.M.; Marzabadi, M.R.; Nagarathnam, D.; Wang, D.; Fang, J.; Miao, S.W.; Hong, X.; Forray, C.; et al. Identification of a Dihydropyridine as a Potent A1a Adrenoceptor-Selective Antagonist That Inhibits Phenylephrine-Induced Contraction of the Human Prostate. J. Med. Chem. 1998, 41, 2643-2650. [CrossRef]

5. Sainani, J.B.; Shah, A.C.; Arya, V.P. Synthesis of 1,4-Dihydro-2,6-Dimethyl-4-(Substituted Phenyl)-5-N-MethylaminocarbonylPyridine-3-Carboxylate. Indian J. Chem. Sect. B Org. Chem. Incl. Med. Chem. 1994, 33, 573-575.

6. Hisaki, M.; Kashima, K.; Sakamoto, Y.; Hojo, M.; Katayama, O.; Hata, H. 3-Aminocarbonyl-1,4-dihydropyridine-5-carboxylic Acid Compounds, and Pharmaceutical Composition Containing the Same. Patent US4874773A, 17 October 1989.

7. Kato, T.; Noda, M. Studies on Ketene and Its Derivatives. LXXXI. Reaction of $\beta$-Aminocrotonamide with $\alpha, \beta$-Unsaturated Ketones. Chem. Pharm. Bull. 1976, 24, 1408-1410. [CrossRef]

8. Chiba, T.; Takahashi, T. Studies on Amino Acid Derivatives. IV. Synthesis of 3-Amino-2 (1H)-Pyridone Derivatives Using 4-Ethoxymethylene-2-Phenyl-5-Oxazolone. Chem. Pharm. Bull. 1985, 33, 2731-2734. [CrossRef]

9. Brown, D.J.; Cowden, W.B. Unfused Heterobicycles as Amplifiers of Phleomycin. V. A Range of Pyridinylpyrimidines with Strongly Basic Side Chains. Aust. J. Chem. 1982, 35, 1203-1207. [CrossRef]

10. Kato, T.; Chiba, T.; Sasaki, M. Reaction of 3-Aminocrotonamide with Nitriles. Heterocycles 1981, 16, 577-580. [CrossRef]

11. Sato, M.; Ogasawara, H.; Kato, T. Reaction of $\beta$-Aminocrotonamide with Dibasic Acid Derivatives. J. Heterocycl. Chem. 1983, 20, 87-91. [CrossRef]

12. Katagiri, N.; Koshihara, A.; Atsuumi, S.; Kato, T. Reaction of $\beta$-Aminocrotonamide with N-Acylated Amino Acid Esters to Give 2-Acylaminoalkyl-6-Methylpyrimidin-4 (3H)-Ones and Their Ring Closure with Polyphosphoric Acid (PPA). Chem. Pharm. Bull. (Tokyo) 1983, 31, 2288-2295. [CrossRef]

13. Katagiri, N.; Koshihara, A.; Atsuumi, S.; Kato, T. 2-[(Acylamino)Methyl]-6-Methylpyrimidin-4(3H)-Ones. Novel Precursors for the Synthesis of Imidazo[1,5-a]Pyrimidines and Imidazo[4,5-b]Pyridines. J. Org. Chem. 1982, 47, 167-169. [CrossRef]

14. Bischoff, C.; Schröder, E. Heterocyclenbildung Mit Enaminen. J. Prakt. Chem./Chem.-Ztg. 1992, 334, 711-715. [CrossRef]

15. Zankowska-Jasinska, W.; Golus, J.; Kamela, Z.; Kolasa, A. Oxalyl Chloride in Furan- and 1H-Pyrrole-2,3-Dione Syntheses. Pol. J. Chem. 1987, 61, 141-148.

16. Shaw, G.; Sugowdz, G. IsoOxazolones. Part VI. The Hydrogenation of 5-Aminoisooxazoles. A New Synthesis of Pyrimidines. J. Chem. Soc. 1954, 0, 665-668. [CrossRef]

17. Goerdeler, J.; Horn, H. Über Isothiazole, IV. Substituierte 5-Amino-Isothiazole Und Isothiazolo[5.4-d]Pyrimidine. Chem. Ber. 1963, 96, 1551-1560. [CrossRef]

18. Baldwin, A.G.; Rivers-Auty, J.; Daniels, M.J.D.; White, C.S.; Schwalbe, C.H.; Schilling, T.; Hammadi, H.; Jaiyong, P.; Spencer, N.G.; England, H.; et al. Boron-Based Inhibitors of the NLRP3 Inflammasome. Cell Chem. Biol. 2017, 24, 1321-1335. [CrossRef]

19. Brough, D.; Allan, S.M.; Freeman, S.; Baldwin, A.G. Cyclic Diarylboron Derivatives as NLRP3 Inflammasome Inhibitors. WO2017017469A1, 2 February 2017.

20. Šimůnek, P.; Pešková, M.; Bertolasi, V.; Macháček, V.; Lyčka, A. Synthesis, NMR and X-Ray Characterisation of 6-Substituted 4-Amino-5-Aryldiazenyl-1-Arylpyridazinium Salts. Tetrahedron 2005, 61, 8130-8137. [CrossRef]

21. Josefík, F.; Svobodová, M.; Bertolasi, V.; Šimůnek, P. A Simple, Enaminone-Based Approach to Some Bicyclic Pyridazinium Tetrafluoroborates. Beilstein J. Org. Chem. 2013, 9, 1463-1471. [CrossRef]

22. Šimůnek, P.; Pešková, M.; Bertolasi, V.; Lyčka, A.; Macháček, V. Formation of Pyridazinium Salts by Azo Coupling of N-Substituted 3-Amino-1-phenylbut-2-en-1-ones and Diazonium Salts. Eur. J. Org. Chem. 2004, 2004, 5055-5063. [CrossRef]

23. Šimůnek, P.; Svobodová, M.; Bertolasi, V.; Macháček, V. Facile and Straightforward Method Leading to Substituted 4-Amino-1Arylpyrazoles. Synthesis 2008, 11, 1761-1766. [CrossRef]

24. Šimůnek, P.; Svobodová, M.; Macháček, V. Synthesis and Characterization of Some 3-Acyl-4-Amino-1-Aryl-1H-Pyrazoles. J. Heterocycl. Chem. 2009, 46, 650-655. [CrossRef]

25. Šimůnek, P.; Macháček, V.; Svobodová, M.; Růžička, A. Some New Information on the Formation of Substituted 4-Amino-1Substituted Phenyl-1H-Pyrazoles from $\beta$-Enaminones and Diazonium Tetrafluoroborates. J. Heterocycl. Chem. 2011, 48, 780-786. [CrossRef]

26. Brož, B.; Padělková, Z.; Bertolasi, V.; Šimůnek, P. A Simple New Hydrazine-Free Synthesis of Methyl 1,4,5-Trisubstituted 1H-Pyrazole-3-carboxylates. Mon. Chem.-Chem. Mon. 2013, 144, 1013-1019. [CrossRef]

27. Pešková, M.; Šimůnek, P.; Bertolasi, V.; Macháček, V.; Lyčka, A. Novel 5-(4-Substituted-Phenyldiazenyl)-1,3,2 $\lambda^{4}$-Oxazaborines and Their Rearrangement to 1,2,4,3 $\lambda^{4}$-Triazaborines. Organometallics 2006, 25, 2025-2030. [CrossRef] 
28. Svobodová, M.; Bárta, J.; Šimůnek, P.; Bertolasi, V.; Macháček, V. Straightforward Access to Oxazaborines, Diazaborinones and Triazaborines by Reactions of $\beta$-Enaminoamides with 4-Methylbenzenediazonium Tetraphenylborate. J. Organomet. Chem. 2009, 694, 63-71. [CrossRef]

29. Josefík, F.; Svobodová, M.; Bertolasi, V.; Šimůnek, P.; Macháček, V.; Almonasy, N.; Černošková, E. A New Bicyclic Oxazaborines with a Bridged Nitrogen Atom, Their Thermic Rearrangement and Fluorescence Properties. J. Organomet. Chem. 2012, 699, 75-81. [CrossRef]

30. Svobodová, M.; Šimůnek, P.; Macháček, V.; Štruncová, L.; Růžička, A. Four-Coordinate Organoboron Compounds from $\beta$ Enaminonitriles and Diazonium Salts. Tetrahedron 2012, 68, 2052-2060. [CrossRef]

31. Josefík, F.; Mikysek, T.; Svobodová, M.; Šimůnek, P.; Kvapilová, H.; Ludvík, J. New Triazaborine Chromophores: Their Synthesis via Oxazaborines and Electrochemical and DFT Study of Their Fundamental Properties. Organometallics 2014, 33, 4931-4939. [CrossRef]

32. Giardina, G.A.M.; Sarau, H.M.; Farina, C.; Medhurst, A.D.; Grugni, M.; Raveglia, L.F.; Schmidt, D.B.; Rigolio, R.; Luttmann, M.; Vecchietti, V.; et al. Discovery of a Novel Class of Selective Non-Peptide Antagonists for the Human Neurokinin-3 Receptor. 1. Identification of the 4-Quinolinecarboxamide Framework. J. Med. Chem. 1997, 40, 1794-1807. [CrossRef]

33. Štefane, B.; Polanc, S. A New Regio- and Chemoselective Approach to $\beta$-Keto Amides and $\beta$-Enamino Carboxamides via 1,3,2-Dioxaborinanes. Synlett 2004, 4, 698-702. [CrossRef]

34. Macháček, V.; Bertolasi, V.; Šimůnek, P.; Svobodová, M.; Svoboda, J.; Černošková, E. A Three-Dimensional Channel Supramolecular Architecture Based on 3-Amino-2-(4-dimethylaminophenyldiazenyl)-1-phenylbut-2-en-1-one and Aromatic Guests. Cryst. Growth Des. 2010, 10, 85-91. [CrossRef]

35. Otwinowski, Z.; Minor, W. Processing of X-Ray Diffraction Data Collected in Oscillation Mode. Macromol. Crystallogr. Part A 1997, 276, 307-326. [CrossRef]

36. Blessing, R.H. An Empirical Correction for Absorption Anisotropy. Acta Crystallogr. Sect. A 1995, 51, 33-38. [CrossRef] [PubMed]

37. Altomare, A.; Burla, M.C.; Camalli, M.; Cascarano, G.L.; Giacovazzo, C.; Guagliardi, A.; Moliterni, A.G.G.; Polidori, G.; Spagna, R. SIR97: A New Tool for Crystal Structure Determination and Refinement. J. Appl. Crystallogr. 1999, 32, 115-119. [CrossRef]

38. Sheldrick, G.M. A Short History of SHELX. Acta Crystallogr. Sect. A 2008, 64, 112-122. [CrossRef] [PubMed]

39. Nardelli, M. PARST95-An Update to PARST a System of Fortran Routines for Calculating Molecular Structure Parameters from the Results of Crystal Structure Analyses. J. Appl. Crystallogr. 1995, 28, 659. [CrossRef]

40. Spek, A.L. Structure Validation in Chemical Crystallography. Acta Crystallogr. Sect. D 2009, 65, 148-155. [CrossRef]

41. Farrugia, L.J. WinGX Suite for Small-Molecule Single-Crystal Crystallography. J. Appl. Crystallogr. 1999, 32, 837-838. [CrossRef]

42. Kato, T.; Yamanaka, H.; Shibata, T. Studies on Ketene and Its Derivatives-XIII: Synthesis of $\beta$-Aminocrotonamide and the Structure of Its Pyrolysed Product. Tetrahedron 1967, 23, 2965-2971. [CrossRef]

43. Kato, T.; Yamanaka, H.; Kawamata, J.; Shimomura, H. Studies on Ketene and Its Derivatives. XXVIII. Reaction of $\beta$ Aminocrotonamide with Ketene and Diketene. Chem. Pharm. Bull. 1969, 17, 1889-1895. [CrossRef]

44. Hansen, K.B.; Rosner, T.; Kubryk, M.; Dormer, P.G.; Armstrong, J.D. Detection and Elimination of Product Inhibition from the Asymmetric Catalytic Hydrogenation of Enamines. Org. Lett. 2005, 7, 4935-4938. [CrossRef] [PubMed]

45. Stahl, I. 1,3-Dithienium- Und 1,3-Dithioleniumsalze, III. Synthese Cyclischer Dithioacetale von $\beta$-Ketoestern Aus KetenSilylacetalen. Chem. Ber. 1985, 118, 3159-3165. [CrossRef]

46. Gelbard, G.; Lin, J.; Roques, N. Reductions with NADH Models. 3. The High Reactivity of Hantzsch Amides. J. Org. Chem. 1992, 57, 1789-1793. [CrossRef]

47. Sato, T.; Yamamoto, K.; Fukui, K.; Saito, K.; Hayakawa, K.; Yoshiie, S. Metal-Catalysed Organic Photoreactions. Photoreactions of 3,5-Dimethylisoxazole with and without Catalytic Assistance by Copper(II) Salts. J. Chem. Soc. Perkin Trans. 1 1976, 7, 783-787. [CrossRef] 